\title{
Risk governance: Examining its Impact upon Bank Performance and Risk-Taking
}

\begin{abstract}
As policy-makers in the United States contemplate a relaxation of financial regulation, our study contributes to this dialogue by testing the veracity of heightened standards of risk governance activities for US bank holding companies (BHCs). Our study examines evidence relating to the adoption of these standards by BHCs following regulatory intervention. We find that board-level risk appetite practices have a profound association upon BHC performance and tail risk. Our estimates show that BHCs which adopt risk appetite practices exhibit a significant improvement in headline performance and reduced tail risk measures. Our research is relevant to academics by identifying the significance of this risk governance practice which has been introduced by global regulators. For practitioners (including board members, risk managers, policy-makers and regulators), our study validates the efficacy of risk appetite frameworks as the future shape of financial regulation is being actively debated in the US.
\end{abstract}

Keywords: Risk, governance, risk appetite, BHCs, financial institutions, boards of directors, bank regulation

\section{INTRODUCTION}

Ineffective oversight contributed to the financial crisis, that plagued the global economy from 2007 to 2009. ${ }^{1}$ Excessive risk-taking was a leading cause of the financial crisis, resulting in significant costs (Conyon, Judge \& Useem, 2011; Gao, Liao \& Wang, 2013; Luttrell, Atkinson \& Rosenblum, 2013). Since the financial crisis, global debt levels have increased by a sum of $\$ 70$ trillion to $\$ 237$ trillion (Bloomberg, 2018), which includes government borrowings to fund bailouts. In the US, there were 387 bank failures over the three years ending 2011, up from 28 failures over the preceding three years (FDIC, 2018). Investors in certain banks saw the value of their holdings nearly destroyed (Beltratti \& Stulz, 2012). Beyond these economic costs, the social impact of financial crises is great, including a reduction in life expectancy, an increase in HIV-related health issues, a decline in the availability of education and increased poverty levels (van Dijk, 2013). The financial crisis was the most severe economic event in the US since the Great Depression (Bolton, 2009). 
Shortfalls in risk management are characterized by a failure to identify, measure, monitor and communicate risk exposures; it is the purview of top management and the board of directors to set the level and types of risks to be undertaken (Stulz, 2008). Improved corporate governance depends upon the board of directors and senior management to determine the firm's risk appetite (Dermine, 2013; Basel, 2015). Risk profiles can be undertaken by managers and traders which may underweight low probability events that lead to tail risk related losses (Kashyap, Rajan \& Stein, 2008; Ellul, 2015). Tail risk cannot be fully mitigated by external supervision or market discipline alone, given shortcomings in measurement systems and the level of opacity exhibited in financial institutions (Ellul, 2015). Banks that fail to embrace robust internal risk monitoring are at risk being exposed to greater tail risk levels (Ellul \& Yerramilli, 2013). Risk appetite is top management's assessment of the expected effect upon the bank's risk profile and valuation of taking on risky investments and activities (Stulz, 2015). Thus, risk appetite practices provide a framework for the board and senior management to improve internal monitoring activities in the post financial crisis environment (Gontarek \& Bender, 2018).

In the years following the financial crisis, policy attention shifted from capital and liquidity metrics to risk-taking oversight and conduct arenas (IMF, 2014; Basel, 2015; G30, 2015). Supervisors introduced enhanced risk governance measures to address perceived lapses in internal monitoring, including the adoption of risk appetite frameworks (Jackson, 2014; Yoost, 2014). We examine several risk governance features, including the board-level articulation of risk appetite, the role of the risk committee and the chief risk officer (CRO). Our study exploits a significant research gap, which is timely given the potential relaxation of bank regulation currently under discussion in the US. The results of our study can be summarised as follows: BHCs that adopt board-level approved risk appetite frameworks exhibit a robust positive association to a suite of performance measures and a negative relation to tail risk, when controlling for other performance and risk-taking determinants. ${ }^{2}$ Upon examination through the lens of agency theory, our study suggests that this practice is consistent with robust internal board-level monitoring activity, which augments direct external monitoring and market discipline as external corporate governance mechanisms. 
The study makes several contributions to the understanding of risk governance. ${ }^{3}$ First, from a practitioner perspective, it disseminates evidence regarding the impact of risk appetite upon performance and risk-taking, relevant to bank directors and senior management given the demands to balance competing risk and return objectives. Next, for regulators, this research validates the adoption by BHCs of risk appetite practices as a robust internal monitoring tool. From an academic perspective, our study probes the literature on bank corporate governance and identifies a gap relating to risk appetite and BHC outcomes. It also provides evidence of a significant association between the adoption of risk appetite arrangements and an array of performance measures and tail risk. We assert that risk appetite has thus far received limited attention and should be considered as a potential explanatory variable in future empirical research.

This article is structured as follows: Following the introduction, we describe the regulatory intervention, present a review of the literature and develop our hypotheses for testing. Afterwards, we discuss the data collected and methodology employed. We then examine the empirical relationship between risk governance mechanisms and a suite of outcome measures. Our conclusions follow presentation of the research findings.

\section{INTERVENTION}

Bank boards failed to exercise adequate oversight of risk-taking prior to the financial crisis. The de Larosière Report (2009) and Walker (2009) state that ineffective risk monitoring contributed to the severity of the crisis. Ellis, Haldane and Moshirian (2014) argue that the financial crisis unveiled bank governance failures at multiple levels, including ineffective bank risk monitoring. Weaknesses included the failure of board directors to establish and adhere to concise risk appetite profiles (SSG, 2009, 2010; Walker, 2009; IIF, 2011; McConnell, 2016). ${ }^{4}$ 
Following the financial crisis, policy-makers such as CEBs (2010), EBA (2011), IIF (2011) and the G30 (2012) embraced heightened risk governance and proposed the adoption of risk appetite practices. Bank regulators followed with new requirements for risk appetite arrangements in Canada, Singapore, Europe, the UK and US (OSFI, 2013; MAS, 2013; CRD IV, 2014; BOE, 2015a and 2015b; Grant Thornton, 2014).5 The Federal Register (2014a and 2014b) disseminated formal US risk governance guidance relating to the Dodd-Frank Act. These US standards impose significant new duties upon BHC boards of directors. US BHCs with assets of more than $\$ 50$ billion are required to establish and monitor compliance to risk appetite frameworks at the board level (Federal Register, 2014a), establish a risk committee (with adequate levels of expertise), and ensure CRO independence and expertise levels (Federal Register, 2014b).

The risk appetite statement is the articulation by the board of directors of the aggregate level and types of risk that the firm is willing to assume or avoid in order to achieve its business objectives (IIF, 2011; FSB, 2013; Basel, 2015).6 The Basel (2015) guidance cites over 40 references to risk appetite, up from zero in its 2006 version. The current Basel corporate governance guidelines were re-issued in part to emphasize the role of risk appetite at the risk committee level (Basel, 2015).

Basel (2015) expects the responsibilities of the board of directors to include:

- Establishing (along with the $\mathrm{CRO}$ ) the bank's risk appetite taking into account its ability to manage risk effectively,

- Overseeing firm adherence to the risk appetite statement and risk limits,

- Monitoring the firm's compensation approach and assess its alignment to its risk appetite,

- Ensure the risk appetite statement includes both qualitative and quantitative considerations, and

- Communicating the firm's risk appetite effectively throughout the bank and linking it to daily decision-making. 
The Senior Supervisors Group (SSG) $)^{7}$ sought to ensure a demonstrable improvement in articulating their risk appetite (SSG, 2010). In Europe, supervisors have indicated that banks face economic, financial, regulatory and other business headwinds, thereby underscoring the importance of an effective risk appetite framework as a means to mitigate excessive risk-taking (EBA, 2016). Consultants advise banks of the importance of risk appetite practices, arguing that it will lead to timely risk-aware decision-making, align resources, and facilitate satisfying performance management targets (Nestor, 2010; Oliver Wyman, 2013; Deloitte, 2014). The ECB (2016) recently performed an in-depth assessment of boards and their risk appetite frameworks for all significant financial institutions in Europe and found room for improvement remains, especially during the earlier stages of its adoption as well as inclusion of the interests of key stakeholders.

Seminal conceptual studies posit that a well-governed bank identifies, measures and aggregates risk to ensure that its actual risk profile is consistent with its risk appetite; but taking-on no risk at all is not a realistic outcome (Stulz, 2015). Dermine (2013) argues that the board should protect the legitimate interests of all relevant stakeholders while establishing its risk appetite and tolerances. Effective articulation of risk appetite should lead to improved asset quality and bank performance levels (Alix, 2012; Jackson, 2014; Mollah \& Liljeblom, 2016). Surprisingly however, little empirical research has been disseminated to date regarding its impact upon BHC performance and risk-taking, exposing the research gap we seek to exploit.

\section{LITERATURE REVIEW}

\section{Risk Governance}

Practically speaking, a long-standing board-level responsibility is to provide effective internal monitoring (Fleischer, Hazard and Klipper, 1988; Macey \& O’Hara, 2003; Claessens \& Kodres, 2014; Macey \& O’Hara, 2016). Risk governance is a key internal monitoring activity of the board (de Andres \& Vallelado, 2008; Aebi, Sabato \& Schmid, 2012; Basel, 2015a; Iqbal, Strobl and Vähämaa, 2015; Ellul, 2015). 
Banks exhibit unique structural features from non-financial firms (Fama, 1980; Levine, 2004; Mülbert, 2010; Becht, Bolton and Roëll, 2011; Sarra, 2012; Laeven, 2013). Banks are highly leveraged compared to nonfinancial entities, amplifying potential gains and losses and resulting in risk-shifting and potentially moral hazards (Bolton, 2010; Hopt, 2013; Laeven, 2013; Mamatzakis \& Bermpei, 2015). Banks exhibit opaque risk profiles given the use of credit extensions, loan modifications and product level complexities, which present further portfolio monitoring challenges (Greenspan, 1996; Levine, 2004; Hopt, 2013; Grove \& Cook, 2013; Hagendorff, 2014). As such, the true extent of their risk profiles may be difficult to discern by the directors, as well as creditors, shareholders and the rating agencies (Ellul, 2015).

Competent and effective risk oversight by the board of directors is critical to balancing agency conflicts (John \& Senbet, 1998; O’Sullivan and Kinsella, 2011). Thus, boards require effective processes to carry out their responsibility of internal monitoring over this risk and reward trade-offs (Ellul, 2015; Chen \& Lin, 2016; Gontarek \& Bender, 2018). While being regulated, banks are also subject to satisfying shareholder performance expectations, underscoring the need for a framework to balance risk-related agency conflicts (de Andres \& Valleldo, 2008; Maati \& Maati-Sauvez, 2012). Deposit insurance may reduce incentives for effective monitoring (de Haan \& Vlahu, 2015). Banks operate in fast moving capital markets, presenting oversight issues as risk profiles can change rapidly (Becht, Bolton \& Roëll, 2011; Prager, 2013). These challenges complicate the role of the board, dictating a heightened duty of care in making informed and risk-aware decisions (Macey and O'Hara, 2016). Given these challenges, agency conflicts can have a pronounced impact upon the interests of all bank stakeholders inside and outside the firm (Dermine, 2013; de Haan \& Vlahu, 2015).

Make no mistake about it, banks take risks every day as part of their business model. They take credit, market, liquidity, business and operational risks, but the expected gains should ideally outweigh economic or reputational costs (Stulz, 2015). Good risk governance does not therefore eliminate all risks (Stulz, 2015). Rather, effective risk governance should lead the board to establish protective risk appetite boundaries and tolerance levels, which is communicated and respected across the firm. A well-governed bank must assess 
value-maximizing trade-offs between risk and reward resulting in ex ante benefits to the firm, thus generating a positive net present value (Stulz, 2015). Banks should mitigate so-called bad risks that fail this standard (Stulz, 2015). In fact, risk appetite practices should identify both desirable and un-desirable risks for dissemination across the firm (Alix, 2012).

Corporate governance mechanisms relate to bank risk-taking (Switzer \& Wang, 2013; Ellul \& Yerramilli, 2013). Boards appear to have failed to appreciate the extent of risk-taking prior to the crisis. Many financial firms lacked adequate internal risk controls and risk reporting tools (Lang \& Jagtiani, 2010). Specifically, some boards failed to establish mechanisms to ensure effective articulation and monitoring of risk appetite (Sabato, 2009; United Nations, 2010; Kumar \& Singh, 2013). Policy-makers observe that banks that correctly balanced risk appetite to their risk management capabilities avoided costly unexpected losses in the crisis (SSG, 2008). Unfortunately, the articulation of risk appetite was not always seen as an essential core responsibility of the board (Charkham, 2003; Moody's, 2005; Prager, 2013). Bank boards suffered from a lack of consensus and information quality on risk appetite during the financial crisis (Nestor, 2010; Pirson \& Turnbull, 2011).

The failure of HBOS Plc in the UK provides a case-in-point of the inadequate articulation and monitoring of risk appetite. The HBOS board failed to implement an effective risk appetite framework (BOE, 2015c). Each HBOS division was responsible for setting its own risk appetite, but no group-wide risk appetite was established until 2007, by which time the crisis was fast approaching. The board gave insufficient priority to risk management, failed to develop and embed risk appetite with quantitative risk targets, and failed to articulate responsibility for setting and monitoring risk appetite in its Board Control Manual (BOE, 2015c). HBOS failed to monitor risk-taking through a single group-wide committee. Notably, the corporate loan division carried $f^{9}$ billion of credit exposure essentially outside its risk appetite (BOE, 2015c). All of this evidence points to a weak risk governance environment at HBOS. With the benefit of hindsight, the implementation of the HBOS group-wide risk appetite statement during the 2010-2014 business planning process was "too little and, proved, much too late" (McConnell, 2016). 
In another notable vignette, the Financial Crisis Inquiry Report (2011) chronicles one occasion at Merrill Lynch in 2007 when business-line executives reported upwards to the board for the first time about a material $\$ 32$ billion build-up of sub-prime credit exposure. This was an obvious case of the board failing to establish, monitor and cascade downwards a clear risk appetite boundary over its trading division and receiving timely reporting of risk exposure, resulting in a significant impact to the firm's performance. If it is the responsibility of the firm's board and senior management to fully understand the bank's risk profile (Basel, 2006), then these two examples show the failures of effective internal risk monitoring and the potential for the build-up of so-called tail risks, at that time.

A maturation of risk appetite practice has since occurred. The OCC today requires risk appetite arrangements to be specifically articulated and monitored by the boards of covered US BHCs (Federal Register, 2014a). Moreover, the board of directors must actively oversee its risk-taking activities and hold management accountable for adhering to the risk appetite framework. It must challenge, or when necessary, oppose, management decisions that might cause excessive and imprudent risk-taking. Banks are placing increasing emphasis on risk governance processes as a means of preventing the build-up of excessive risk profiles to reduce downside risks and risk appetite arrangements are at the centre of this shift in bank behaviour (Jackson, 2014; Ernst \& Young, 2015). Risk appetite is taking a prominent place in the suite of risk governance mechanisms of financial institutions (Alix, 2014; Gontarek, 2016). Risk appetite frameworks must be aligned with staff compensation and remuneration schemes, as one simple means to facilitate a robust risk culture across the firm (ECB, 2018). Best practices for risk appetite focus on linking risk appetite with performance assessment and advancement and compensation (Yoost, 2014).

Risk appetite practices holds promise to facilitate risk identification for the firm's board and c-suite executives which are outside of its capacity to safely manage risk. Conceptual literature argues that effective risk appetite arrangements ensure that acceptable risks are undertaken, aligning resources with profitable investment and investment decisions, to a achieve a positive impact upon performance (Sabato, 2009; Jackson, 2014). 
The use of risk appetite, when combined with a strong risk culture, infrastructure and incentives, can lead to improved firm performance (Alix, 2012; G30, 2015). In summary, a bank's risk appetite is an assessment by top management of the expected effect of the bank's risk-taking and the value of the trade-off of undertaking riskier investments and activities (Stulz, 2015).

Tail-risk has been defined as a rare outcome that can have a devastating effect upon a bank's balance sheet (Kashyap, Rajan \& Stein, 2008; Ellul, 2015). Without robust internal monitoring, decision-making processes relating to these risk-return trade-offs may be entangled in corporate politics, the source of several large notable risk management failures (Ellul, 2015). Examples include the Merrill Lynch vignette noted above and events at UBS in 2008. Ivantsov (2016) defines the tail risk related event at UBS for example as an extreme cliff risk directly impacting performance when crystallised, with sub-prime and related super-senior related losses of over $\$ 35$ billion between 2007 and early 2008 .

Tail risks may be curtailed by robust internal monitoring activities (Ellul \& Yerramilli, 2013). Tail risks may occur when superficial risk management practices fail to identify and mitigate low-probability outcomes that later turn out to be significant to the firm's rijk profile. Tail risks cannot be fully contained by supervision or market discipline alone, given risk measurement challenges, strong incentives, and product-level complexities which obscure the true nature of risk-taking and value creation (Ellul \& Yerramilli, 2013). Tisk appetite as an internal risk governance mechanism may contribute to the containment of tail risks which otherwise may go on un-monitored by external monitoring mechanisms.

Sabato (2009) explains that firms articulate their risk appetite (desired risk profile) and risk capacity (maximum tolerance for risk-taking) by linking concentration limits, economic capital levels, and the cascading and embedding of risk appetite effectively within the business unit. Boards should be composed of directors who are capable of acquiring and processing information to effectively assess major risks and adjudicate the correct level of risk appetite (Mülbert, 2010; Wymeersch, 2012; Lam \& Potter, 2012; Ellul, 
2015). Validating risk appetite is vital to the corporate governance framework of financial institutions and cascading it to the business line facilitates consistent risk-based decision-making (Davies, 2013; Lam, 2014; McConnell, 2016). Ellul (2015) explains that excessive risk-taking can destroy value when a bank's actual risk profile departs its optimal targeted level of risk-taking.

Bank Director (2016) provides a glimpse into the current use of risk appetite practices, reflecting the regulatory shift towards this risk governance activity. According to this report, 94 per cent of firms with assets greater than $\$ 10$ billion confirm that establishing risk appetite is a key responsibility of the board risk committee. It also reports that $67 \%$ of banks with assets greater than $\$ 1$ billion communicate the risk appetite framework to all employees. Risk appetite arrangements are now emerging as a key risk governance practice (Oliver Wyman, 2013; Yoost, 2014; CRO Forum, 2015). However, until now, little or no empirical evidence exists to assess the veracity of risk appetite frameworks as an risk governance practice.

Beyond risk appetite practices, risk governance includes the role and experience level of the board-level risk committee. ${ }^{8}$ In the US, covered BHCs (as well as publicly-traded BHCs with assets of more than $\$ 10$ billion), must establish and maintain standalone risk committees to oversee risk management (Federal Register, 2014b). The risk committee, which considers forward-looking risk-based issues, should be distinct from the audit committee. Deloitte (2017) reports that $100 \%$ of larger US banks now have a dedicated risk committee separate from its audit committee, up from $85 \%$ in 2014. Walker (2009) reports that fundamental issues considered by the risk committee should include prudential risks, such as leverage and capital, liquidity, market, operational (including technology and cyber risks), and business risks (i.e., reputational/brand, conduct and ethical risks). Yeh, Chung \& Liu (2011) find that financial institutions that exhibit greater degrees of independence within the risk committee performed better in the financial crisis.

Board-level risk committee members increasingly interface with supervisors on detailed risk-related issues facing the firm across the credit, market and operating risk spectrum. The Federal Reserve evaluates directors on their ability to identify, measure and control risk (Macey and O'Hara, 2016). Risk committee 
chairmen ideally should exhibit a mastery of the subject matter of their committees in order to foster debate and shape committee risk-taking decision-making (Carrott, 2013). The heightened risk governance standards in the US also require covered BHCs to ensure that the risk committee has at least one member with risk expertise in identifying, assessing, and managing risk exposures (Federal Register, 2014b, p. 17286).

Boards with strong risk committees may be less likely to undertake excessive risk-taking (McNulty, Florackis \& Ormrod, 2013). Independent directors on risk committees stand in a better position to challenge managerial power and mitigate agency conflicts (Yeh, Chung \& Liu, 2011). Little empirical research has been disseminated regarding bank risk committee size, a proxy for influence and effectiveness. Battaglia and Gallo (2015) find a positive relation for risk committee size and performance for Asian banks while Al-Haidi, Hasan \& Habib (2015) find a positive relationship between larger risk committee size and levels of market disclosure. This indicates a further gap in the literature for empirical examination.

Thus far, there is limited evidence if any that the existence of a risk committee drives performance (Aebi, Sabato \& Schmid, 2012; Hines \& Peters, 2015). In fact, the latter authors posit that risk management committees may represent a symbolic governance practice to enhance the firm's reputational legitimacy (Hines and Peters, 2015, p. 288).

The existing evidence presented within related literature examining directors' risk expertise levels is mixed. On the one hand, Fernandes and Fich (2013) find that the presence of experienced directors is associated with reduced risk exposure prior to the crisis, greater stock returns and lower TARP funding. Hau and Thum's (2009) examination of the demographic details of supervisory board members reveals that competence levels relate positively to performance. Iselin (2016) finds that risk committees provide effective stewardship of bank capital, as BHCs with risk committees are associated with greater capital levels during periods of crisis. 
However, other research challenges these positions. Findings presented by Andries and Brown (2014) report that greater expertise on bank boards is associated with rapid pre-crisis credit growth and greater credit contraction after the crisis. Seminal research by Minton, Taillard and Williamson (2014) examine US BHCs and find that independent directors' expertise is strongly associated with greater risk-taking and lower BHC performance during the crisis period.

Risk committee charters describe and delineate the roles, responsibilities, objectives and qualifications of its members (Chapman and Cutler, 2016). Risk committee charters should specifically include approval of the risk appetite statement and its articulation across the business (Deloittes, 2014, 2016). One study reports that 86 per cent of the board-level risk committees of large US banks have developed risk committee charters (Deloitte, 2016), providing a glimpse into the risk governance activities of the board including monitoring processes of risk-taking.

Beyond risk appetite activities and the risk committee, the role of the $\mathrm{CRO}$ is an important actor in risk governance structures (Mikes, 2008, 2010; Gontarek, 2016). CRO experience and independence is considered important to the regulator, given the requirement in the US for each BHC to be satisfied that the $\mathrm{CRO}$ possess the relevant experience for a BHC of commensurate size, structure, risk profile, complexity, activities and size (Federal Register, 2014a). The CRO may report to the chief executive officer (CEO) and/or board risk committee (Walker, 2009) and will typically enjoy direct access and risk reporting to board's risk committee without impediment (ECB, 2016). In seminal research, Aebi, Sabato and Schmid (2012) find that BHCs where the CRO reports directly to the board of directors (and not to the CEO) exhibit higher (i.e., less negative) stock returns and ROE during the crisis. Lingel \& Sheedy (2012) evaluate risk governance features in an international sample and find that the CRO's presence on the executive team and compensation are important determinants for risk-taking behaviours (along with board-level risk committee characteristics). In one review of risk committee charters, it is noted that the risk committee must approve the appointment or dismissal of the CRO as well as remuneration levels in $73 \%$ of large US banks, up from 46\% in 2014 (Deloittes, 2016). 


\section{Other Corporate Governance Characteristics}

Other board characteristics may explain the relationship with BHC performance and/or risk-taking. Board size has an ambiguous relation with performance. Larger forums face communication and co-ordination challenges, strengthening the hand of management (Jensen, 1993). Some research suggests that larger boards are associated with improved performance as more directors contribute to monitoring of the firm (Adams \& Mehran, 2012) while other research suggests it is associated with greater risk-taking (IMF, 2014). Notable studies find a complex relation between board size and performance, where larger boards improve performance to a certain extent before tapering off in an inverted U shape function (de Andres \& Valleldo, 2008).

Mamatzakis \& Bermpei (2015) find that investment bank board size is robustly and negatively related to bank performance, supporting the agency-costs hypothesis with this sample. Aebi, Sabato \& Schmid (2012) posit that board size, as a corporate governance mechanism, may be substituted by external monitoring, possibly explaining the variety of findings in the literature.

The extent of board level meetings (Vafeas, 1999), including board-level meeting frequency (Hahn \& Lasfer, 2016) may demonstrate a level of internal monitoring and strong corporate governance in the banking industry although greater meetings may also denote the need for greater oversight given under-performance, or so-called re-active boards (Vafeas, 1999; de Andres \& Vallelado, 2008).

Another aspect of board structure is the proportion of non-inside directors as they can mitigate agency conflicts between management and shareholders. Fama and Jensen (1983) argue that external directors may have reputational motivations, and thus exercise diligent internal monitoring. Director independence has been potentially linked to greater protection of creditor interests and thus may serve as a brake on excessive risk-taking (Vallascas, Mollah \& Keasey, 2017). Some studies find that non-insider board member representation is largely unrelated to risk-taking or performance (IMF, 2014; Grove et al., 2011), whereas others observe greater director independence is associated with lower risk-taking (Switzer \& Wang, 2013). 
Some literature finds independent directors potentially detrimental to the interests of shareholders, as further equity was raised in the crisis resulting in wealth transfers between owners and creditors (Erkens, Hung \& Matos, 2012). The evidence remains ambiguous thus far on non-inside directors.

The level and power of institutional shareholders may impact outcomes. Institutional shareholders can have the power, influence and incentives to monitor risk-taking and performance in banks (Laeven \& Levine, 2009; Gropp and Köhler, 2010; Berger et al., 2015) or alternatively drive greater risk-taking possibly resulting in greater losses over time (Aebi, Sabato \& Schmid, 2012). This latter position resonates with Erkens, Hung \& Matos (2012) who found greater board level independence pre-crisis was related to greater BHC risktaking.

Age and experience may be related characteristics in the context of financial performance and risk-taking. Citing upper echelons theory, Hambrick and Mason (1984) argue that executive characteristics make a difference to the quality of decision-making and thus performance. Mikels and Reed (2009) study the role played by age in financial decision-making and establish a greater risk-taking capacity in younger adults, whereas mature adults have more experience in complex decision-making (Worthy et al., 2011). Nguyen, Hagendorff and Eshraghi (2015) catering for executive age in their study of US banks. They conclude that younger executives may have greater incentives to engage in riskier and value-destroying activities, incurring greater agency-related rents. Grove et al., (2011) measure the age of board directors and find that older directors are positive for performance to a point after which the benefits taper-off.

\section{Hypothesis Development}

In our study, the null hypothesis is that adoption of risk appetite practices has a positive impact on BHC performance measures. With respect to risk-taking and inspired by Ellul \& Yerramilli (2013), we also hypothesize that risk governance, and specifically in this case risk appetite practices, should have a negative relation with tail risk, all else equal. This risk governance practice is a clear feature of robust risk management and internal monitoring - a framework to identify risks and take corrective actions as needed at the most 
senior levels of the firm as risk and return trade-offs are assessed. Tail risks respond to robust risk governance and internal monitoring activities, which may not be fully captured by the regulator's oversight and external market discipline (Ellul \& Yerramilli, 2013; Ellul, 2015). As such, tail risk is our primary risk measure. The alternative hypothesis is that risk appetite arrangements are window-dressing and largely ceremonial practices adopted by banks in response to regulatory fiat, thus having no discernible impact at all upon BHC outcomes.

\section{Data and Variables}

\section{Data}

Since the data collected includes a combination of both time-series and cross-sectional data, panel data analysis is employed as an efficient empirical tool (de Andres and Vallelado, 2008). Time dummies are used to control for yearly effects. The following equation is estimated where the BHC outcome may be performance or risk-taking outcomes:

\section{Equation 1:}

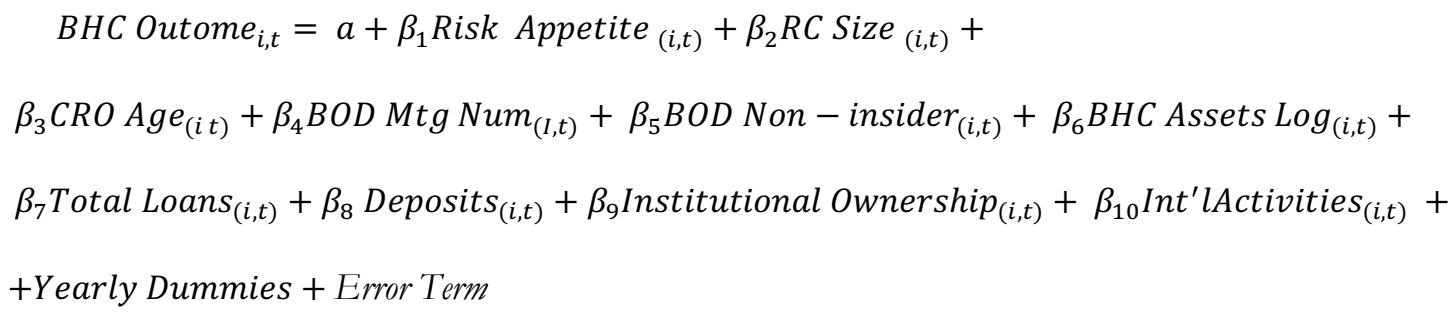

Where Performance ${ }_{i t} \in\{$ ROA, ROE, Other Operating Income, Holding Period Returns (HPRs) $\}$

Where Risk $_{\mathrm{it}} \in\{$ Loan Loss Provisions (LLPs), the $\mathrm{z}-$ score and Tail Risk $\}$ 
In the above equation, the subscript $i$ denotes the BHC and $t$ denotes the year of the observation. This model allows us to control for important corporate governance and BHC business model characteristics that may affect BHC performance or risk-taking outcomes.

\section{Sample Selection}

The chosen sample consists of 140 large US BHCs, for the period 2012 to $2015 .{ }^{9}$ This sample covers a significant proportion of the US banking system with over $\$ 11$ trillion or $70 \%$ of total US banking system assets. The Federal Reserve's website of the largest BHCs was used to identify the sample BHCs, and BoardEx was used to remove intermediate holding companies (IHCs) which are not applicable to this study as foreign owned subsidiaries. The largest BHCs are subject to the suite of risk governance changes, while smaller BHCs may or may not implement these arrangements notwithstanding the lack of formal requirement. The sample comprised 560 firm-year observations for the fiscal years 2012 to 2015. The full list of BHCs within in the sample is found in Appendix I.

\section{Risk \& Corporate Governance Variables}

The corporate governance variables relate to the strength of the internal monitoring function. Our key risk governance variable is the activity of establishing and articulating the risk appetite statement at the boardlevel risk committee. Data on the articulation of risk appetite by the board are collected from individual risk committee charters retrieved from BHC websites and on-line ${ }^{10}$. For each BHC, the unambiguous existence of board-approved risk appetite statement approved by the board and/or its risk committee is coded as 1 (exists) or 0 (does not exist) for each year in the study.

We examine the size of the risk committee as an explanatory variable (de Andres \& Vallelado, 2008; Battaglia, Curcio \& Gallo, 2014; Ellul \& Yerramilli, 2013). As this study focuses on risk governance and the role it may play in performance and risk-taking, the role of the risk committee is considered (Iselin, 2016; Chapman and Cutler, 2016). The size of the risk committee can serve as a proxy for willingness to invest in board-level resources, a sign of influence and stature, and thus represent greater governance (Hines et al., 
2015). The number of risk committee members is used in our study, following Tao \& Hutchinson (2013) and Hines et al. (2015). We collect this information from BoardEx.

In the US, CROs of large BHCs are required to have relevant experience in identifying, assessing, and managing exposures of large complex financial institutions (Federal Register, 2014). Berger, Kick and Schaeck (2014) examine demographic features of executives and bank risk-taking (including age) as an effective substitute for workforce experience. They find that younger management teams significantly increase bank portfolio risk and that risk profiles decline with advanced age of executives. The age of senior executives is used as an explanatory variable in banking studies such as Grove et al. (2011) and Cooper \& Uzun (2012). Older c-suite executives in banks are related to lower levels of risk-taking (Switzer \& Wang, 2013). We use CRO age as a proxy to estimate the level of experience and maturity of the CRO as a key risk governance actor and collect this data from Bloomberg.

McNulty, Florackis and Ormrod (2013) argue that high effort norms by directors lead to lower risk-taking. Board meeting frequency reflects the degree of monitoring efforts (Hahn and Lasfer, 2016). Attending board meetings is one of the basic standards to meet US bank director diligence requirements (Adams and Ferreira, 2012; Chou, Chung, \& Yin, 2013). Board meetings are a means to assess internal monitoring efforts (Aggarwal and Williamson, 2006). We measure this variable as the number of meetings attended as a percentage of total meetings held per annum, following Battaglia and Gallo (2016) and Aebi, Sabato and Schmid (2012). We collect this data via Bloomberg.

The ratio of non-inside directors to total directors is an often-used explanatory variable in bank corporate governance studies (Mehran, Morrison and Shapiro, 2011; Battaglia \& Gallo, 2016). Non-inside directors have no employment relationship with the company except for their board seat. This data is collected via BoardEx. We also collect the level of involvement by institutional shareholders as a control variable following Aebi, Sabato \& Schmid (2012), Switzer \& Wang (2013) and Berger et al., (2015). Institutional shareholders may have the power, influence, incentives and access to monitor or drive bank risk-taking and 
thus performance (Laeven and Levine, 2009). We collect the ratio of institutional ownership shareholdings to total shareholdings from Bloomberg.

\section{Bank Level Variables}

In our regressions, we control for various bank level characteristics that may explain bank performance or risk-taking, including BHC size (Demsetz, Saidenberg \& Straham, 1997; Chen et al., 2011; Dietrich and Wanzenried, 2011; Switzer and Wang, 2013). BHC year-end total assets are collected from the US Federal Reserve Board and its log value is employed in our estimations. BHC size is associated with growth, scale and business strategies (Iqbal, Strobl and Vähämaa, 2015). For example, BHC asset size is statistically related to the number of BHC subsidiaries (Avraham, Selvaggi and Vickery, 2012), suggesting that oversight of larger organisations may be more complex than smaller firms.

Controlling for $\mathrm{BHC}$ business model differences are taken into account with the $\mathrm{BHC}$ size as noted above but also by examining traditional bank characteristics including the significance of loans on the asset side and deposit funding on the liabilities side of the balance sheet. Total loans to total assets follows Kupiec \& Lee (2012); Minton, Taillard \& Williamson (2014); and Battaglia \& Gallo (2016) and is used to capture the relative impact of these business model drivers. Banks with fewer loans (and a greater extent of non-lending businesses such as transaction banking, sales and trading, custody or payments, advisory and investment banking) may exhibit different performance or risk profiles than a bank heavily centred on the provision of credit products to its clients primarily.

Deposits to total assets (deposits) is collected following Aebi, Sabato \& Schmid (2012) and Ellul \& Yerramilli (2013). These variables control for balance sheet composition and profitability (ECB, 2010b; Ellul \& Yerramilli, 2013). Banks that attract deposits with relative ease may perform better, notably during challenging funding market conditions (Dermine \& Schoenmaker, 2010; Hoque, 2013). We collect both of these business control variables from Bloomberg. 
The extent of BHC international activity may be a determinant in risk-taking levels. Monitoring overseas operations may exacerbate agency problems (Lee \& Kwok, 1988). Rather than benefiting from the diversification of clients within new geographies, evidence shows that US banks with international activities have higher risk profiles and lower lending standards (including weaker loan covenants) than purely domestic banks (Berger et al., 2015). In essence, this suggests that additional international market risks outweigh any benefit of international diversification. We collect the percent of international activities of BHC total income from Bloomberg.

\section{Outcome (Dependent) Variables}

Bank performance provides a yardstick for relative value judgments of commercial banks and their success. Performance and risk measures are examined herein through a suite of headline outcome variables. Return on assets (ROA) is used as an accounting-based BHC outcome variable (Giroud and Mueller, 2010; ECB, 2010a; Xu, Grove and Schaberl, 2013; Aebi, Sabato and Schmid, 2012; Battalgia and Gallo, 2015). ROA is defined as the cumulative annual net income for each year divided by that year's total assets. Return on equity (ROE) is also used often as a bank performance metric in empirical research; it takes into account the equity capital deployed to generate returns. Palvia (2011) calls ROE a standard measure of bank accounting performance. We use ROE following Aebi, Sabato \& Schmid (2012); McNulty \& Akhighbe (2017); and Elyasiani \& Zhang (2015). Both variables are collected from Bloomberg.

Copeland (2012) and Avraham, Selvaggi, and Vickery (2012) report that larger BHCs generate significant non-traditional income streams which results in greater organizational complexity and arguably well covered by risk governance processes including risk appetite frameworks. Other operating income is employed within our estimations as a dependent variable to reflect those underlying volatile sales and trading or investment banking revenue channels which may be underpinning the headline performance measures. These studies generally conclude that income streams associated with non-conventional business lines tend to be more volatile than interest-based activities and may be relevant to larger covered BHCs in our study. Other operating income is calculated as other operating income divided by total assets and all data is 
collected from Bloomberg. Finally, we turn to stock holding period returns (HPRs) as a market-based performance measure following Beltratti \& Stulz (2011); Aebi, Sabato \& Schmid (2012); and Peni \& Vahämaa (2012). HPRs are collected from Bloomberg.

We collect risk-based outcome variables for our estimations, including loan loss provisions (LLPs). LLPs are measured as the loan loss provision divided by total assets and is collected via Bloomberg. LLPs has been previously examined in the literature (Kanagartnam \& Lobo, 2003) as a source of reserves for potential future bad debts that may later become uncollected. Positive values (an increase in LLPs) may also reflect a form of income smoothing, thus a sign of effective corporate governance practice (Fonseca \& González, 2007; Zagorchev \& Gao, 2015).

Next, we calculate the $\mathrm{z}$-score in our estimations as a risk outcome for each BHC. ${ }^{11}$ The z-score is inversely related to the probability of bank insolvency (Roy, 1952). We choose the bank z-score as it predicts bank failure with a high accuracy and is highly correlated with the Merton (1974) distance-to-default measure, another widely used bank risk measure in the literature. Beltratti \& Stulz (2011), Belghitar \& Clark (2012), Demirgüç-Kunt \& Huizinga (2011), Bai \& Elyasiani (2013) and Berger et al. (2015) use the z-score as a risk measure in a related context. A higher z-score indicates higher profitability levels to cover debt expenses and thus a more stable financial institution. We follow Laeven \& Levine (2009) and define the z-score as the sum of the mean value of the annual ROA plus the mean value of the capital asset ratio or "CAR", divided by the standard deviation of annual ROA for over each of the preceding four years. The z-score is described further below:

\section{Equation 2:}

$$
Z-\text { score }_{t}=\frac{\mathrm{E}(R O A)_{t \rightarrow t-3}+\mathrm{E}(C A R)_{t \rightarrow t-3}}{\sigma(R O A)_{t \rightarrow t-3}}
$$


Next, following Ellul \& Yerramilli (2013) and Battaglia \& Gallo (2016), we calculate BHC tail risk. BHC tail risk is the negative of the average return on the BHC's stock over the $5 \%$ worst return days. Tail risk data is collected from Bloomberg. BHCs with an independent and effective risk management function should have lower enterprise-wide tail risk, all else equal (Rajan, 2005, Kashyap, Rajan \& Stein, 2008). The need to mitigate tail risk rises from agency related pressures leading to excessive risk-taking by executives or traders combined with the limitations of regulatory supervision and external (Ellul \& Yerramilli, 2013). Tail risk is that rare outcome that has the potential to have a devastating effect when it materialises (Ellul, 2015). This is precisely when effective internal monitoring activities become crucial to a bank's overall risk profile.

In summary, our suite of dependent variables includes performance measures ROA, ROE, other operating income and HPRs while the risk outcome variables include LLPs, the z-score and tail risk. Our suite of dependent variables includes both accounting and market determined measures. All variables are also defined in Appendix 2.

\section{Empirical Analysis}

\section{Descriptive Statistics}

Table 1 reports the descriptive statistics for our measure of BHC performance and risk-taking, the corporate governance and risk governance variables and business level control variables. Mean annual ROA performance for the sample period was $1.02 \%$ in our study. This compares with a mean ROA of 1.10 per cent reported by Ellul and Yerramilli (2013) and 1.20 per cent by Minton, Taillard and Williamson (2014). The mean value of ROE in our study is $9.09 \%$ versus $12.6 \%$ in Switzer \& Wang (2013) and 8.43\% in Aebi, Sabato \& Schmid (2012). As expected, BHC holding period returns performed well during the recovery period post financial crisis with a mean $20.68 \%$ annual return, buoyed by policy intervention post financial crisis. By contrast, Ellul and Yerramilli (2013) report a negative 7 per cent mean annual return for the period including the crisis years. 
Table 1 also reports the suite of risk-related variables, including the average level of loan loss provisions of $0.20 \%$ (versus $0.72 \%$ in Zagorchev \& Gao's (2015) sample which included the crisis period). The mean value of tail risk is $-27.56 \%$ versus $4.7 \%$ which included the crisis period in Ellul \& Yerramilli (2013). The z-score value is 10.61, versus 8.81 in Garcia-Sánchez et al. (2017), and 7.40 in Berger et al. (2015).

Risk appetite arrangements are published and articulated by an average of nearly $27 \%$ of BHCs in the sample, having increased from $15 \%$ in 2012 to $42 \%$ by 2015 . The mean number of risk committee members is 5.0 , versus 3.9 reported in Battaglia \& Gallo (2015) and 4.91 in Hines et al. (2015). The average age of the CRO in our study is 54.9 years, compared to 49.2 years for the CFO in Switzer \& Wang (2013). Coles, Daniel \& Naveen 2008 report CEO age levels of 55.3 years whereas Pathan \& Skully (2010) reports 56.9 years. In our study, each BHC has on average $86 \%$ of non-insider directors, versus $72 \%$ in Elyasiani \& Zhang (2015) and $79 \%$ in de Andres \& Vallelado (2008). A mean value of 10.1 board meetings is observed across our sample, versus Adams \& Mehran's (2012) 8.4 board meetings, 10.4 observed in Battagia, Curcio \& Gallo (2013) and 10.48 observed in Grove et al. (2011).

In terms of $\mathrm{BHC}$ business level variables, the mean value of $\mathrm{BHC}$ assets is $\$ 74.90$ billion, versus $\$ 82.89$ billion in Elyasiani \& Zhang (2015). The mean total loans percentage is $64.2 \%$ of total assets, versus $62.6 \%$ in Ellul \& Yerramilli (2013) and 66.9\% in Zagorchev \& Gao (2015). The mean value of deposits (as a percentage of total assets) is $74.5 \%$ in our study, versus $68.7 \%$ in Ellul \& Yerramilli (2013), $73.9 \%$ in Aebi, Sabato \& Schmid (2012) and 73.8\% in Zagorchev \& Gao (2015).

[Insert Table 1 about here]

\section{Correlation Analysis}

Table 2 presents the Pearson-pairwise correlation analysis for the variables. Risk appetite is positively correlated to performance variables including ROA, ROE, other operating income, and LLPs. Items of further note includes a positive correlation value for risk appetite and BHC size, not surprising given the 
fact that all covered BHCs are required to adopt this risk appetite arrangements as of late 2014. International activities are positively correlated with the other income variable, while negative correlation is noted for the total loans and international activities, suggesting more internationally active banks are also less likely to be involved in lending businesses and instead may embrace transactional banking, investment banking, and sales and trading activities. However, we caution any further interpretations at this stage given the lack controls for other explanation of BHC performance or risk-taking with simple pairwise correlation analysis.

[Insert Table 2 about here]

\section{Multi-variate Analysis - Performance \& Risk}

We begin our multi-variate analysis by first examining the determinants of BHC performance by estimating panel regressions of the form presented in Equation 1 above.

The results of our estimations are presented in Table 3 . The first relevant dependent variable is ROA in the first output column. The coefficient for risk appetite in Table 3 indicates a positive and one per cent significant relation between risk appetite and ROA. BHCs that practice risk appetite arrangements report improved ROA performance by 23.5 basis points, on average. Total loans is also positively and significantly related to ROA, suggesting the bread and butter business of banking, making loans, may be relatively attractive for BHCs during the sample period. The coefficient for board meeting frequency and ROA is negative and significant, indicating meeting frequency declines with greater BHC performance, suggesting firms with more board meetings require greater oversight and governance intensity. The next column in Table 3 also presents the model for determinants of BHC ROE. Risk appetite is not only positive and one per cent significant, but its coefficient value is 1.65 suggesting a material increase of $165 \mathrm{bps}$ in ROE levels for those BHCs that adopt risk appetite activities.

Table 3 considers the determinants of other operating income in the following column. Risk appetite practices undertaken by BHCs are positive and significantly related to higher levels of other operating 
income. This suggests one underlying channel of performance driver in the headline returns noted above may originate from non-traditional banking activities, including sales and trading, investment banking, advisory and other more volatile sources of revenue as noted earlier. Interestingly, BHC size, board meeting frequency and deposits are negatively and significantly related to other operating income in this model, while board non-insiders, total loans and institutional share ownership are all also significantly and positively related to other operating income in this model.

We also report HPRs the estimations for BHC holding period returns (HPRs). This model indicates that adopters of risk appetite are not significantly related to HPRs, notwithstanding the positive relation that exists for this risk governance activity and accounting-led performance measures. Stock markets apparently may fail to take notice to the emerging risk governance practice of articulating risk appetite.

Next, we observe in Table 3 the estimation results for the three risk-related variables. We start by examining loan loss provisions (LLPs). In this model, a positive (but insignificant) coefficient is reported for risk appetite and LLPs. Interestingly, CRO age exhibits a negative and significant coefficient value for LLPs, indicating as CROs age, the value of LLPs decline. Board non-insider measure is positively and one per cent significant for LLPs, consistent with earlier research suggesting improved corporate governance also is related to the income smoothing hypothesis and greater LLPs (Zagorchev \& Gao, 2015). Table 3 also reports a positive but not significant relationship for risk appetite and the z-score.

Lastly, we review the results of our estimations for risk appetite and tail risk in the final column of Table 3. In this model, we observe a negative one per cent significant relationship between risk appetite and tail risk, indicating BHCs that practice risk appetite arrangements exhibit lower tail risk. As noted above, BHCs that exhibit high tail risk may produce short-term gains but are at risk of a devastating loss later. Such risks are not solely addressed by direct regulatory oversight or market discipline, but require intense internal monitoring (Ellul, 2015). We next consider this practice on a lagged-basis to investigate for any relation that may exist. 
[Insert Table 3 about here]

Multi-variate Analysis - Performance \& Risk (Lagged)

Tables 4 and 5 reports the results of our estimations for the determinants of BHC performance and risktaking on a one and two-year lagged basis respectively, so we examine both at the same time within this section of the paper.

We first observe our results for risk appetite and ROA in Table 4 which indicate that firms that practice risk appetite have a positive and one per cent significant relationship on a one-year lagged basis, which is also reported in Table 5 for a two-year lagged basis. Both models in Tables 4 and 5 also consistently report a negative and one per cent significant relation between board meeting frequency and ROA, indicating greater board meeting frequency relate significantly to lower BHC performance. In fact, the same relation exists in the following columns for both ROE and other operating income on both a one and two-year lagged basis. The determinants of ROE on a lagged basis are also presented in Tables 4 and 5. Once again as in un-lagged estimations, BHCs that adopt risk appetite frameworks exhibit a one percent significant and positive relation to ROE for both one and two-year lagged basis. In these models, total loans and international activities both also exhibit a positive relation to ROE, again validating the role that these two variables play as a determinant for BHC performance, though the effect is only significant in Table 4.

Tables 4 and 5 report the determinants of other operating income. As with the un-lagged estimations, those BHCs that adopt risk appetite processes report higher other operating income at a one-percent statistically significant level in both a one and two-year lagged basis. Effectively designed risk appetite arrangements would certainly cover those activities that are captured by this income and business category, including advisory, transaction banking, sales and trading, investment banking and other non-traditional banking businesses. This again adds further evidence as to the underlying channel of outperformance observed in the headline return variables we report. 
As before, risk appetite is not significantly related to HPRs, this time on a lagged basis, confirming the lack of acknowledgement of this activity by the equity markets notwithstanding its clear association with accounting performance.

Now we examine the determinants of risk measures on a lagged basis.

We begin by evaluating the determinants of loan loss provisions on a lagged basis in Tables 4 and 5 . Consistent with the predictions of Wahlen (1994) and Zagorchev \& Gao (2015), we find that this corporate governance activities, in this case the practice of setting BHC risk appetite, is positively and significantly related to loan loss provisions, resonating with the income smoothing hypothesis. Banks that adopt risk appetite practices also report higher loan loss provisions. We observe a positive coefficient at the one and five percent significant level for risk appetite with one and two-year lags respectively in these models. Also, on a lagged basis in Tables 4 and 5 , we consider the impact of this risk governance activity upon the z-score. The one-year lagged estimation report a positive relation at the five percent significance level (dropping to 10 percent in the two-year lag), suggesting that adopting BHCs exhibit an improvement of their distanceto-default risk profile and an improvement in their credit profiles one and two years after adopting this risk governance practice. Lastly, we evaluate the determinants of tail risk on a lagged basis. The coefficient value for risk appetite remains negative but insignificant in lagged estimations.

In summary, we have thus far estimated the relationship of a suite of risk governance mechanisms to BHC outcome measures. We observe a consistent and statistically significant relationship between the emerging boardroom practice of risk appetite practices and selected BHC performance measures for both an unlagged and on a lagged basis. The relation with other variables including risk-taking measures are more complex and less consistent than in the case of the performance variables, with the exception of tail risk. In the next further analysis section, we examine a sub-sample of BHCs to appreciate how BHC size or the nature of the regulatory response may have manifested itself upon mandatory adopters only. 
[Insert Tables 4 and 5 about here]

\section{Multi-variate Analysis - Further Analysis: Mandatory Adopters}

We now delimit larger BHCs which are mandatory adopters of risk appetite arrangements as defined in the Federal Register (2014a) from those that are smaller and not subject to the heightened regulatory standards. Both larger (mandatory) and smaller BHCs may have adopted risk appetite practices, but we argue that their motivations for doing so are different. Mandatory adopters must demonstrate their compliance with this practice whereas voluntary adopters choose to do so and may have other motivations to follow this practice, consistent with institutional theories of corporate governance, such as box-ticking exercises. Once again, we apply the same model set-up. In Table 6 for each dependent variable, we have estimated a suite of regressions for only for BHCs that are mandatory adopters of risk appetite (or those banks with greater than $\$ 50$ billion in assets) in order to isolate only their determinants of BHC performance and risk-taking.

In Table 6, we report the results for performance for mandatory adopters of risk appetite arrangements. These regressions are re-estimated again and reported for our full suite of dependent variables. The coefficient values remain positive and significant at the five per cent level for ROE and other operating income. The later result continues to support the possible outperformance originates from the channel of non-traditional banking activities such as sales and trading as well as investment banking, traditionally more volatile source of revenue. The relation of risk appetite to ROA is positive and only ten per cent significant in this model. These results for the determinants of performance in this model suggest that mandatory adopters are exhibiting a positive impact from adopting this risk governance.

Further evidence is noted in this model when examining the impact of risk committee size and other operating income. The coefficient in this model is negative and five percent significant, indicating smaller risk committees may be playing an active role in risk governance relating to those more volatile and nontraditional banking activities that feed into this outcome measure. Across the performance models and now 
the $\mathrm{z}$-score, BHCs that are required to adopt risk appetite practices as noted by the Federal Register (2014a) consistently report a robust positive relationship to the dependent variable.

Mandatory adopters of this risk governance practice exhibit a positive association across several BHC performance measures, including ROA, ROE, other operating income and the z-score. If mandatory adopters failed to display a positive relation, this might call into question the efficacy of this internal monitoring practice as seen through the lens of agency theory. However, the evidence presented is contrary to this position and continuation of the association between risk appetite practices and selected outcomes remains robust.

In summary, here we have isolated those BHCs that are expressly covered by the enhanced requirement for risk appetite practices from smaller BHCs that may or may not adopt these measures on a voluntary basis. We observe in our examinations that larger mandatory BHCs which adopt this practice continue exhibit a relation to a suite of $\mathrm{BHC}$ outcome measures. As before, this risk governance activity is not associated with the holding period returns of the BHC but primarily accounting variables. In the next section, we employ different empirical approaches including alternative explanations for our findings, consider the potential for omitted variables, and conduct a differences-in-differences analysis to extend our examination and test our findings further.

[Insert Table 6 about here]

\section{Robustness - Examining Risk Committee Expertise}

The Federal Register (2014a and 2014b) disseminated the new risk governance practices applicable to BHCs, and we have conducted an examination relating to risk appetite statements, the existence of the risk committee and the age of the CRO (as a proxy for CRO experience). 
But other risk governance impacts introduced at the same time may be driving the results observed in our study. We thus identify from this regulatory change another potential exploratory variable which has been recently adopted that may otherwise be driving our findings. Beyond the presence of a risk committee, the heightened risk governance standards also require covered BHCs to ensure that the risk committee has at least one member with risk expertise in identifying, assessing, and managing risk exposures (Federal Register, 2014b, p. 17286). This expertise requirement provides a further opportunity to test the role of the risk committee in our study for any linkage to BHC outcomes.

The existing evidence found within the literature relating to directors' risk expertise levels is mixed as noted above. In view of the mixed position taken by the academic literature, board-level risk committee member expertise can be now probed with BHC performance and risk outcomes, given the unambiguous requirement voiced by bank supervisors for experienced risk committee members at the board level. The new predictor variable in this next battery of estimations is risk committee financial expertise which is the percentage of risk committee members with the relevant executive expertise as defined in seminal literature. ${ }^{12}$ This definition is also found in the Appendix 2.

Table 7 presents the results of the determinants of BHC performance and risk-taking, now including BHC risk committee financial expertise as the key explanatory variable. We retain risk appetite as an explanatory variable within these estimations as well. In nearly all models, risk committee financial expertise as an explanatory variable is not significantly related to our suite of BHC outcome measures, calling into doubt its role in explaining our earlier findings. However, the retained explanatory variable, risk appetite, continues to exhibit a positive and significant relation across the same suite of relevant performance variables, whereas the coefficient for tail risk weakens in significance but remains negative.

There are two exceptions of note. First, is the relationship of risk committee expertise and HPRs (which also was not significant in earlier estimations). Interestingly, this suggests that stock markets value the expertise and possibly composition of the risk committee over the activities they perform such as risk 
governance duties. The final outcome variable of note is the $z$-score that reports a one percent negative value for BHCs with experienced risk committee members, suggesting risk committee members may be able to tolerate greater risk-taking by the BHC, as measured by the z-score, versus less experienced members, also as noted in Minton, Williamson and Taillard (2014).

Empirical predictions easily may have been different, as financial expertise should produce lower costs of acquiring and processing financial data and information related to complex banking activities and driving performance gains (Minton, Taillard and Williamson, 2014). However, this feature of recently introduced risk governance does not explain our earlier results, which thus remain in good standing so far. ${ }^{13}$

[Insert Table 7 about here]

\section{Robustness - Mitigating Omitted Variables}

We next seek to mitigate omitted variables and include other reasonable explanatory variables in our analyses (Antonakis et al., 2010) by adding an extended suite of controls upon further consideration of the literature, following Vyas (2011) and Black \& Kim (2012).

We noted earlier that board size is an often-used explanatory factor linked to BHC performance and risktaking, as informational requirements for larger or more complex banks call for larger boards to share the burden of monitoring (Pathan \& Skully, 2010). As noted earlier, the literature is ambiguous about this corporate governance mechanism, with Adams \& Mehran (2012) finding a positive relation between these variables while literature by Pathan and Faff (2013) and more recently Mamatzakis \& Bermpei (2015) suggests board size has a negative relation to performance. We collect from Bloomberg the number of directors for each year of the sample as an explanatory variable for our next round of estimations. The average number of BHC directors is 11.9 . 
Our research could also be criticised for failing to recognize important agency dynamics between management and shareholders (Berle \& Means, 1932; Jensen \& Meckling, 1976). The incentives for risktaking by bank management will depend on the extent to which their interests are aligned to shareholders (Saunders, Strock \& Travlos, 1990; Demsetz, Saidenberg \& Stahan, 1997). CEOs are well placed to limit or allow excessive risk-taking (Fortin, Goldberg \& Roth, 2010; Gropp \& Köhler, 2010; Aebi, Sabato \& Schmid, 2012).

Unlike diversified investors, CEOs may lose a significant portion of their invested wealth if the BHC fails (Devriese et al., 2004). Thus, CEO share incentives, which play an increasingly important role in overall CEO remuneration, may provide incentives relating to risk-taking (Pathan, 2009). While CEO remuneration consists typically may consist of cash, bonus and equity-related incentives, we focus on the market value of shares held by the CEO given its potential to be a determinant in BHC performance or risk-taking. Adams \& Mehran (2003) reports that on average each BHC CEO holds nearly $\$ 28$ million in shares, lower than non-financial firm CEOs but still a sizable sum. Fahlenbrach \& Stulz (2011) report a positive relation between executive remuneration and share performance for US banks. Pathan (2009) and Pathan \& Skully (2010) employ a measure of CEO share ownership as a proxy to examine CEO power. In the former, the author finds that strong boards are associated with more BHC risk-taking, whereas strong CEOs can serve as a bulwark against excessive risk-taking. This resonates with Fortin et al. 2010, who examine US BHCs and finds that bank CEOs with greater power, achieved via share ownership or other mechanisms, take less risk. We collect the market value of BHC shares held by BHCs CEOs from Bloomberg and employ its log value for the next set of estimations. The average value for this variable is USD 15.9 million.

CEO power may relate to CEO duality where power is concentrated with one governance actor, hindering monitoring (Hermalin \& Weisbach, 1998; Chen, Lin \& Yi, 2008; Pathan, 2009). Pi and Timme (1993) posit that duality can lead to exacerbated agency conflicts. They find a negative relationship between duality and performance, consistent with Grove et al. (2011), who also find that duality is negatively related to ROA and market returns. However, Byrd et al. (2012) present empirical evidence that the presence of duality for 
a sample of US thrifts was related to lower failure rates, on average, during the 1980s. This latter result resonates with Mamatzakis \& Bermpei (2015) who finds duality has a significant and positive result on performance, which chimes with stewardship theories of corporate governance that indicate that a powerful CEO serves as a prudent steward of the firm's asset base and risk profile (Donaldson \& Davis, 1991). CEO duality information is collected from BoardEx. CEO duality is measured with a dummy variable taking a value of 1 if the same individual holds the Chairman and CEO role, and 0 otherwise. CEO duality is observed in $52 \%$ of our sample.

The inclusion of these further explanatory variables in our baseline estimations does not alter our overall findings, in unreported results. Risk appetite records a one-percent significant and positive relation to ROA and other operating income whereas ROE records a five-percent significant and positive association with these new explanatory variables added to our baseline estimations. The addition of these expanded variables to our baseline estimations results in tail risk reporting ten percent significant coefficient value, which is weaker than before but still negative.

Across this a battery extended explanatory variables, our initial findings are upheld with respect to the role of the adoption of risk appetite frameworks by the board of directors and BHC outcome measures, notably performance measures. We next turn to a further method of analysis to extend our suite of robustness tests.

\section{Robustness - Differences-in-Differences}

While a randomized experiment would be an ideal remedy to infer causality in empirical research, replicating such opportunities are often practically challenging for researchers (Bertrand \& Mullainathan, 2003). However, another credible means towards inferring a potential causal relationship occurs in corporate governance research when there is simultaneously a change in laws or regulation assessed in a differencesin-differences empirical framework (Love, 2011; Antonakis et al., 2010). 
By employing a differences-in-differences design, we extend our research further with what may be the most remaining credible empirical approach, as it studies events that occur outside the firm's control (i.e., a change in regulation or laws) rather than a change in firm's choices (Love, 2010). The differences-in-differences (DiD) design method has a long history in econometrics generally and in banking-led research specifically. It is used for estimating the effects of policy change or intervention (Lechner, 2010; Black and Kim, 2012). Berger, Roman and Sedunov (2016) assess the impact of the Troubled Asset Relief Program (TARP) on US BHCs using DiD to find that that the bailout led to statistically significant decreases in systemic risk levels. Berger, Kick and Schaeck (2014) consider changes in executive board composition with DiD estimations and find a robust positive relationship between younger executives and risk-taking. Black and Kim (2012) use DiD in their sample of Korean commercial firms after the changes to corporate governance regulations and related laws for large (treated) and small (control) firms and find that the latter enjoy valuation gains making a robust argument towards causality. DiD facilitate an assessment of the impact of regulatory intervention for control and treated groups of BHCs.

The applicable treatment in the context of our research is the adoption of risk appetite arrangements by the BHCs. ${ }^{14}$ The DiD examination offers an alternative technique to assess whether the governance reforms predict a impact upon the dependent variable at the right time and when the reforms are adopted as required by an external change or shock (Black \& Kim, 2008; Love, 2010).

Table 8 illustrates our findings for risk appetite and the suite of BHC performance and risk-taking measures using our existing set of control variables as covariates within the $\mathrm{DiD}$ analysis. Our DiD analysis largely validates our overall earlier findings. The overall DiD results are consistent with our main study regressions. BHCs that adopt risk appetite frameworks unambiguously experience gains in performance measures such as ROA and ROE. Further, the association identified with this risk governance practice and tail risk in our earlier estimations is also validated by the $\mathrm{DiD}$ approach as well. 
The DiD analysis validates our underlying testing for the relationship between risk appetite frameworks and ROA, ROE, and tail risk. Table 8 presents one and five-percent significant positive DiD results between risk appetite and ROA and ROE (respectively) while the relationship with risk appetite and tail risk is five percent significant and negative (e.g., tail risk declines). This analysis illustrates an improved performance or lower risk-taking for those BHCs that have adopted risk appetite at the BHC board level for these three outcomes, adding further evidence to the central role of risk appetite arrangements as an important risk governance activity. The coefficient for risk appetite and other operating income remains positive but losses its significance in this model.

On the whole, these DiD results provide yet further evidence of the impact of risk appetite arrangements upon BHC operating measures, relying on an alternative empirical method employed in corporate governance research following a regulatory change.

Across the robustness section of this paper, we have considered alternative approaches to test the veracity of our findings. First, we examined if other risk governance practices (i.e., risk committee expertise levels) introduced might be driving our results. Next, we sought to mitigate omitted variables risk by re-estimating our model with an expanded set of control variables with qualitatively similar outcomes. Lastly, we deployed a differences-in-differences framework to strengthen our empirical analysis. The results of our robustness tests validate our initial core findings. BHCs that adopt risk appetite practices exhibit improved headline performance measures and report lower tail risks.

The next section presents our conclusions.

[Insert Table 8 about here] 


\section{CONCLUSION}

Given the idiosyncratic nature of the banking industry, including information asymmetries, risk opacity, leverage levels, regulation and resulting systemic risk profile, internal monitoring in banking has been identified as a key corporate governance mechanism (de Andres and Vallelado, 2008; Becht, Bolton \& Roëll, 2011). Following the financial crisis, bank regulators intervened with a set of heightened regulations to improve internal monitoring (Federal Register, 2014, Basel, 2015). Some risks, such as tail risk which can have a devastating impact upon the risk profile of banks, is not fully mitigated alone by external monitoring but require robust risk management practice (Ellul \& Yerramilli, 2013). But simply relying on the existence of larger boards alone as a corporate governance practice appears insufficient as they face coordination issues and other challenges (Upadhyay, Bhargava and Faircloth, 2014; Faleye, Hoitash and Hoitash, 2011). Conventional external corporate governance features (i.e., direct regulation and market discipline) alone may not be enough to curtail excessive risk-taking by banks, relying instead on heightened risk governance features to provide improved oversight (Ellul, 2015).

Heightened risk governance activities were introduced to enhance the scope of internal monitoring. Several risk governance mechanisms codified into law (Federal Register, 2014) have been analysed in this study for their relation to BHC performance measures and risk profiles, including the articulation, approval and monitoring of firm-wide risk appetite.

There is little doubt that banks require a strong and knowledgeable board (Greuning and Bratonovic, 2003). Catering for enhanced risk governance practices including risk appetite impacts the remit and duties of BHC directors and other governance actors (Alix, 2012; Fischer, 2015; Banking Exchange, 2017, Gontarek \& Bender, 2018). Our research suggests rather than observable features of the risk committee (its size or expertise levels, for example), it is the activities performed within these board forums (such as the articulation of risk appetite) that may better explain improvements to selected BHC outcome measures. Risk 
appetite frameworks have a fundamental effect on how banks are managed (Jackson, 2014). However, until now, there has been little empirical testing of the efficacy of this risk governance practice.

Compelling empirical evidence is presented in this study for the adoption of board-level risk appetite arrangements and their positive impact to BHC outcomes. Risk appetite significantly related to a suite of BHC operating performance measures, across a variety of empirical settings. The underlying channel for the outperformance maybe income that originates from sales and trading, investment banking and other more volatile business lines and are themselves potential generators of tail risk.

Further, we observe a robust negative relation between risk appetite practices at the board level and tail risks. Tail risks as noted above cannot be fully mitigated by external monitoring but require robust internal risk governance practice (Ellul \& Yerramilli, 2013, Ellul, 2015). Our findings with respect to lower tail risk appear to be related to in part by the adoption of risk appetite frameworks by BHC boards given the critical role that internal monitoring plays in the mitigation of tail risks (Ellul \& Yerramilli, 2013).

In effect, adopting risk appetite frameworks is associated with both better performing banks that are also less exposed to tail risks, thus promoting long-term value maximization.

Our findings chime with the seminal conceptual predictions. Kashyap, Rajan and Stein (2008) and Ellul (2015) flag the potential for agency conflicts within banks and posit that risk managers were unaware or unable to restrain traders and risk-takers during the financial crisis. Moreover, tail risk cannot be entirely captured by external monitoring and market discipline alone but requires robust governance arrangements to detect and control risks effectively. Risk appetite practices are a critical aspect of better risk management in banks given the agency conflicts present. Our study resonates with Jackson (2014) whom argues that better Risk Appetite articulation by bank boards should improve bank performance. 
The dissemination of risk appetite frameworks to the trading desks, credit underwriting teams, and other operating areas may facilitate the development of a disciplined risk-taking culture if aligned with compensation frameworks, an area of growing focus in practice (ECB, 2016; Gontarek \& Bender, 2018). Ellul and Yerramilli (2013) observe in seminal research that BHCs underlying business model or possibly risk culture may determine the choice of risk and the strength of their risk management system. These authors posit that conservative BHCs may take lower risk and establish stronger risk management systems, while aggressive BHCs take higher risks and put into place weaker risk management controls. Given the evidence presented in this research, the articulation, approval and monitoring of risk appetite boundaries by BHC boards sit comfortably within the former, more cautious risk management ethos noted by these researchers.

Successful risk-taking requires banks to identify good from bad risks (Stulz, 2015). Within our framework, bad risks include those risks which appear profitable in the short-run but can have a devastating impact upon bank balance sheet and asset quality later, thus requiring enhanced internal risk governance (Ellul, 2015). We argue that the articulation, approval and active monitoring of risk appetite by the board risk committee contributes to heightened risk governance as actual risk-taking is more effectively aligned with strategy and the firm's capacity to manage risk.

A somewhat surprising secondary finding is that, while risk appetite arrangements and BHC accounting measures for performance are significantly and positively related, this governance practice is not significantly associated with positive BHC stock returns. This suggests that public security markets may be unaware of the significance of the use of risk appetite arrangements and the potential to impact underlying operating performance. Regulators may consider publishing in their call reports (including BHC Y9 reports) information on the use of risk appetite in order to illuminate this board practice for investors, counterparties and bank customers. This measure might also promote greater market discipline and improve the transparency of BHC risk profiles in historically opaque risk-taking activities. Supervisors may also wish to 
consider risk appetite profiles when generating system-wide stress test scenarios as a tool to capture systemic risks (Woo, Chelluboina \& Xoual, 2014; Dowd, 2016).

Seminal bank corporate governance research call for the development of improved tools that may signal risks in a timelier manner as well as dissemination of risk-based information as a means to enhance monitoring (Claessens and Kodres, 2014). Unless there are robust risk governance practices in place, it may be difficult to constrain excessive risk-taking (Ellul, 2015). Bank supervisors echoed these calls with the requirement to adopt new corporate governance standards: "Another important objective is to emphasize key components of the risk governance responsibility of the board of directors, such as a risk committee, risk appetite and its relationship to a bank's risk capacity" (Basel, 2015).

One expert adds: "Better articulation of risk appetite, facilitated with the appropriate infrastructure and supported by a strong risk culture, should improve firm governance and performance... While global regulators have pushed for progress, this cannot be viewed as simply a regulatory compliance exercise - or it will be doomed to fail" (Jackson, 2014). It is the board's responsibility to judge and monitor the risk appetite of the firm (ECB, 2018). Our research confirms the practice of risk appetite as an important tool of the board of directors and the c-suite of financial institutions. This research is important to researchers facing a dearth of information about an important risk governance practice required by global bank regulators - the articulation of risk appetite by the board of directors. Our study facilitates a better understanding of this practice and its impact upon BHC outcomes, addressing the existing knowledge gap. The existence of risk appetite frameworks as board level practice should be an explanatory variable in empirical research.

Board directors, CEOs and CROs as practitioners will find this research an important validation of the practice of risk govemance. Policy makers and bank supervisors will benefit from our findings when considering the appropriateness of the key risk governance arrangements adopted thus far and respond to calls for a relaxation of bank regulation. Critics argue that the regulatory environment has become costlier. 
BHCs are subject to new direct regulatory costs of some $\$ 2$ billion per year, resulting in lending reductions up to $\$ 20$ billion (Federal Financial Analytics, 2015). Today, there are attempts to reduce the burden of director's duties relating to risk management (Banking Exchange, 2017). While such adjustments may be ultimately appropriate and positive, it is important to be unambiguous about which aspects of the DoddFrank related heightened risk governance requirements appear meaningfully contribute to BHC performance and risk profiles within an evidence-based framework.

This begs the question of whether or not the broad set of heightened risk governance standards introduced in the US post Dodd-Frank Act (Federal Register, 2014a, 2014b) enhance BHC performance levels and reduce risks or alternatively are un-necessary box-ticking exercises. As for risk appetite activities practiced by US bank risk committees, the answer to this question is empirically addressed within this study. This article seeks to contribute meaningfully to the current debate underway in policy circles in the US, as policymakers, practitioners and others shape the future design of corporate governance of banks. 


\section{REFERENCES}

Adams, R. (2012). Governance and the Financial Crisis. International Review of Finance, 12(1), 7-38.

https://doi.org/10.1111/j.1468-2443.2011.01147.x

Adams, R. and Mehran, H. (2003). Is Corporate Governance Different for Bank Holding Companies? FRBNY Economic Policy Review, 9(1), 123-142.

Adams, R. and Mehran, H. (2012). Bank board structure and performance: Evidence for large bank holding companies. Journal of Financial Intermediation, 21 (2012), 243 - 267. DOI: 10.1016/j.jfi.2011.09.002

Adams, R. and Mehran, H. (2005). Corporate Perfomance, Board Structure and Their Determinants in the Banking Industry. Available at: http://papers.ssrn.com/Sol3/ papers.cfm?abstract_id=302593. (Accessed: 4 January 2015).

Adams, R., and Ferreira, D. (2012). Regulatory pressure and bank director incentives to attend board meetings, International Review of Finance, 12(1), 227 - 248. https://doi.org/10.1111/j.1468-2443.2012.01149.x

Aebi, V., Sabato, G. and Schmid, M. (2012). Risk management, corporate governance, and bank performance in the financial crisis. Journal of Banking \& Finance, 36(12), 3213-3226. DOI:10.1016/j.jbankfin.2011.10.02

Aggarwal, R. and Williamson, R. (2006). Did new regulations target the relevant corporate governance attributes? Available at: http:// faculty.msb.edu/aggarwal/governance.pdf (Accessed: 12 January 2015).

Al-Hadi, A., Hasan, M., and Habib, A. (2015). Risk committee, firm life cycle, and market-risk discloures, Corporate Governance: An International Review, 24(2), 145-170. https://doi.org/10.1111/corg.12115

Alexander, G., Baptista, A. and Yan, S. (2015). On regulatory responses to the recent crisis: An assessment of the Basel market risk framework and the Volcker rule. Financial Markets, Institutions \& Instruments. 24, 88-124: DOI: $10.1111 /$ fmii.12025 
Alix, M. 2012. Risk Governance: Appetite, Culture and the Limits of Limits. Federal Reserve Bank of New York. Available at: https://www.newyorkfed.org/newsevents/speeches/2012/alix121114 (Accessed: 13 September 2015).

Alix, M. (2014). Risk Appetite and Risk Culture: A Regulatory View. Risk Culture and Effective Risk Governance, London: Risk Books.

Andries, A. and Brown, M. (2014). Credit Booms and Busts in Emerging Markets, The Role of Bank Governance and Risk Management. University of St Gallen Working Papers of Finance, 14(4), 131-155.

Altman, E. (1968). Financial ratios, discriminant analysis and the prediction of corporate bankruptcy. Journal of Finance. 22, 550-612.

Antonakis, J., Bendahan, S., Jacquart, P., and Lalive, R. (2010). On making casual claims: A review and recommendations. Leadership Quarterly, 21 (2010), 1086 - 1120. Doi:10.1016/j.leaqua.2010.10.010

Bai, G. and Elyasiani, E. (2013). Bank stability and managerial compensation. Journal of Banking \& Finance, 37(3), 799-813. DOI: $10.1002 /$ mde.2653

Bank Director. (2015). The 2015 Risk Practices Survey Summary Report. Available at: http://www.fisglobal.com/ucmprdpub/groups/public/documents/document/c027869.pdf (Accessed: 12 October 2015).

Bank Director. (2016). The 2016 Risk Practices Survey Report. Available at: http://www.bankdirector.com/issues/risk/2016-risk-practices-survey-banks-beef-up-on-cybersecurity/ (Accessed: 5 August 2016).

Banking Exchange (2017). The Board's Role in Risk Management Evolving. Available at: http://www.bankingexchange.com/news-feed/item/7260-board-s-role-in-risk-management-evolving. (Accessed: 2 March 2018).

Bank Safety and Soundness Advisor. (2014). Regulators Push for More Formalized Risk Appetite Statement. Available at: http://www.finpro.us/uploads/1/2/8/4/12842898/072114 bssa newsletter.pdf (Accessed: 20 October 2015). 
Banking Ireland . (2015). Risk Culture is at the forefront of bank's agenda. Available at:

http://www.iob.ie/sites/default/files/Banking Ireland - semi 2015.pdf (Accessed: 30 December 2015).

Barth, J. (2015). Examining the Designation and Regulation of BHC SIFIs. The Statement before the House Financial Services Committee, U.S. House of Representatives. Available at:

http:/ / financialservices.house.gov/calendar/?EventTypeID (Accessed: 1 February 2016).

Basel. (2006). Basel Committee on Banking Supervision. Enhancing Corporate Governance for Banking Organizations.

Available at: http://www.bis.org/publ/bcbs122.htm (Accessed: 13 September 2014).

Basel. (2010). Basel Committee on Banking Supervision (BCBS, 2010), An Assessment of the Long-Term Economic Impact of Stronger Capital and Liquidity Requirements Available at: http://www.bis.org/publ/bcbs173.pdf

(Accessed: 15 August 2015).

Basel. (2015). Basel Committee on Banking Supervision Guidelines. Corporate Governance Principles for Banks. Available at: http://www.bis.org/bcbs/publ/d328.htm (Accessed: 25 August 2015).

Battaglia, F., Curcio, D., and Gallo, A. (2014). Board structure and tail and systemic risk-taking: Evidence form European banks. Available at:

http://www.efmaefm.org/0EFMAMEETINGS/EFMA\%20ANNUAL\%20MEETINGS/2014-

Rome/papers/EFMA2014 0476 fullpaper.pdf (Accessed: 2 January 2015).

Battaglia, F., and Gallo, A. (2015). Risk governance and Asian bank performance: An empirical investigation over the financial crisis. Emerging Markets Review, 30(2015), 1-

16. http://dx.doi.org/10.1016/j.ememar.2015.04.004

Battaglia, F., and Gallo, A. (2016). Strong boards, ownership concentration and EU bank's systemic risktaking: Evidence from the financial crisis. Journal of International Financial Markets, Institutions, and Money, 2016, 1 - 31. doi: 10.1016/j.intfin.2016.08.002

BBA. (2015). Response to Consultative Document on Guidelines for Corporate Governance Principles for Banks. Available at: https://www.bba.org.uk/policy/financial-and -risk-policy/parliamentary-commission-of-banking-stand ards/corporate-governance/bba-response-to-bcbs-corporate-governance-principles-for-banks/ (Accessed: 24 September 2015). 
Berle, A. and Means, G. (1932). The Modern Corporation and Private Property. Indiana Law Journal 8(11). Available at: http://www.repository.law.indiana.edu/ilj/vol8/iss8/11 (Accessed: 14 September 2014).

Becht, M., Bolton, P. and Röell, A. (2011). Why bank governance is different. Oxford Review of Economic Policy 27(3), 437-463. https://doi.org/10.1093/oxrep/grr024.

Belghitar, Y. and Clark, E. (2012). The Effect of CEO Risk Appetite on Firm Volatility: An Empirical Analysis of Financial Firms. International Journal of the Economics of Business 19(2), 195 - 211. DOI:

$10.1080 / 13571516.2012 .642640$

Beltratti, A. and Stulz, R. (2012). The credit crisis around the globe: Why did some banks perform better? Journal of Financial Economics, 105(1), 1-17. doi:10.1016/j.jfineco.2011.12.00

Berger, A., Kick, T., and Schaeck, K. (2014). Executive board composiition and bank risk-taking. Journal of Corporte Finance, 28(30), 48 - 65. http://dx.doi.org/10.1016/j.jcorpfin.2013.11.00

Berger, A., El Ghoul, S., Guedhami, O. and Roman, R. (2015). Internationalization and Bank Risk. Available at: https://www.kansascityfed.org/ /media/files/publicat/reswkpap/pdf/rwp15-08.pdf (Accessed: 27

December 2014).

Berger, A., Roman, R., and Sedunov, J. (2016). Do bank bailouts reduce or increase systemic risk? The effects of TARP on financial system stability. Available at: http://www.cbs.dk/files/cbs.dk/paper allennberger 0.pdf (Accessed: 8 August 2016).

BHC Rating Manual. (2015). The Bank Holding Company Rating System. Available at: https://www.federalreserve.gov/boarddocs/supmanual/bhc/bhc.pdf (Accessed: 4 April 2016).

Black, B., Jang, H., and Kim, W. (2006). Does corporate governance affect firm's market values? Evidence from Korea. Journal of Law, Economics and Organization 22, 366 - 413.

Black, B., Kim, W., Jang, H., and Park, K. (2008). How corporate governance affects firm value: Evidence on channels from Korea. Available at: http://admin.darden.virginia.edu/emUpload/uploaded2009/black-kim-jang-park081208-clean.pdf (Accessed: 4 April 2016). 
Black, B. and Kim, W. (2012). The effect of board structure on firm value: a multiple identification strategy approach using Korean data. Journal of Financial Economics 104(2012), 203 -

226. doi:10.1016/j.jfineco.2011.08.00

Bloomberg. (2008). Global Debt at Record Level. Available at:

https://www.bloomberg.com/news/articles/2018-04-10/global-debt-at-record-level. Accessed:11 April 2018.

BoardEx. (2016). Available at: http://corp.boardex.com/academics/ (Accessed: 14 October 2016).

BOE. (2014). CRD IV. Updates for credit risk mitigation, credit risk, governance and market risk. Available at: http://www.bankofengland .co.uk/pra/Pages/publications/cp/2014/cp1214.aspx Available at: http://www.bankofengland .co.uk/pra/Pages/publications/cp/2014/cp1214.aspx (Accessed: 1 February 2015).

BOE. (2015a). Corporate Governance: Board Responsbilities. The Bank of England - Prudential Regulation Authority Consultation Paper CP18/15. Available at: http://www.bankofengland .co.uk/pra/Pages/publications/cp/2015/cp1815.aspx (Accessed: 25 May 2015).

BOE. (2015b). Internal Governance. The Bank of England - Prudential Regulation Authority Supervisory Statement. Available at: http://www.bankofengland .co.uk/pra/Pages/publications/ss/2015/ss2115.aspx (Accessed: 15 July 2015).

BOE. (2015c). The failure of HBOS Plc. Available at: http://www.bankofengland .co.uk/pra/Documents/publications/reports/hbos.pdf (Accessed: 30 January 2016).

Bolton, B. (2009). The US Financial Crisis: A Summary of Causes and Consequences. Available at: http://papers.ssrn.com/sol3/papers.cfm?abstract id=2133576 (Accessed: 4 November 2015). Bolton, P. (2010). Is Bank Governance Different? Available at: https://www0.gsb.columbia.edu/faculty/pbolton/papers/TCGDconference1010\%20[Compatibility $\% 20$ Mo de].pdf (Accessed: 13 November 2014).

Bolton, P., Mehran, H., and Shapiro, J. 2011. Executive Compensation and Risk-taking. Available at: https://www.newyorkfed.org/medialibrary/media/research/staff reports/sr456.pdf (Accessed: 24 June 2014). 
Booth, J., Cornett, M., Tehranian, H. (2002). Boards of directors, ownership, and regulation. Journal of Banking \& Finance, (2002), 1973 - 1996.

Bugalla, J., Kallman, J., Lindo, S., and Narvaez, K. (2012). The new model of governance and risk management for financial institutions. Journal of Risk. Management in Financial Institutions 5(2), 181 - 193.

Byrd, J., Fraser, S., Lee, D., Tartaroglu, S. (2012). Are two heads better than one? Evidence from the thrift crisis. Journal of Banking \& Finance, (2012), 957 - 967. doi:10.1016/j.jbankfin.2011.10.00

CEBS. (2010). Committee of European Banking Supervisors: High Level Principles for Risk Management. Available at: https://www.eba.europa.eu/documents/10180/16094/HighLevelprinciplesonriskmanagement.pdf (Accessed: 12 September 2014).

Center for Financial Inclusion. (2013). Governing Banks: MFI Edition. Available at: http://www.centerforfinancialinclusion.org/publications-a-resources/browse-publications/512-governingbanks-mfi-edition-part1 (Accessed: 12 June 2014).

Central Bank of Ireland. (2014). Feedback Statement on Risk Appetite - A Discussion Paper. Available at: https://www.centralbank.ie/press-area/press-

releases/Pages/FeedbackStatementonRiskAppetiteDiscussionPaper.aspx (Accessed: 13 January 2015).

Chapman and Cutler. (2016). Risky business: Is it time to consider establishing a separate Risk Committee? A corporate governance quarterly update. Available at http://www.chapman.com/insights-publications-

Risk_Committee_Corporate_Governance.html (Accessed: 3 April 2016).

Charkham, J. (2003). Guidance for the Directors of Banks. The Global Corporte Governance Forum - The World Bank. Available at:

http://www.ifc.org/wps/wcm/connect/bd9bc00048a7e730aa6fef6060ad5911/Focus_2_Guidance_for_Dire ctors_of_Banks.pdf?MOD=AJPERES (Accessed: 20 June 2015).

Chen, C., Barry Lin, J. and Yi, B. (2008). CEO duality and firm performance - an endogenous issue. Corporate Ownership and Control, 6 (1), 58-65.

Chen, C., Li, M., Chou, Y., Chen, L., and Liou, W. (2011). Are large banks less risky? The Services Industry Journal, 31(13), $2111-2116$. 
Chen, H. and Lin, K. (2016). How do banks make the trade-offs among risks? The role of corporate governance. Journal of Banking \& Finance, 2016, 1 - 31. http://dx.doi.org/10.1016/j.jbankfin.2016.05.01

Chiaramonte, L., Liu, F., Poli, F., and Zhou, M. (2016). How accurately can z-score predict bank failures? Finanical Markets, Institutions \& Instruments, 333-360. https://doi.org/10.1111/fmii.12077

Chou, H., Chung, H. and Yin, X. (2013). Attendence of board meetings and company performance: Evidence from Taiwan. Journal of Banking \& Finance, 37(11), 4157 -

4171. http://dx.doi.org/10.1016/j.jbankfin.2013.07.02

Claessens, S. and Kodres, L. (2014). The Regulatory Responses to the Global Financial Crisis: Some Uncomfortable Questions. IMF Working Papers, 14(46), 1-39.

Copeland, A. (2012). Evolution and Heterogeneity amoung larger BHCs: 1994 to 2010. FRBNY Economic Policy Review, 83-93.

Coles, J., Daniel, N. and Naveen, L. (2008). Boards: Does one size fit all? Journal of Financial Economics 51, 371 - 406. doi:10.1016/j.jfineco.2006.08.00

Conference Board. (2014). Risk Oversight: Evolving Expectations for Boards. Available at: http://www.fsb.org/wpcontent/uploads/c_140206w.pdf (Accessed: 4 January 2015).

Conyon, M., Judge, W.Q. and Useem, M. (2011). Corporate Governance and the 2008-09 Financial Crisis. Corporate Governance: An International Review, 19(5), 399-404. doi:10.1111/j.1467-8683.2011.00879.x

Cooper, E., and Uzun, H. (2012). Directors with a full plate: the impact of busy directors on bank risk, Managerial Finance, 38(6), 571 - 586. http://dx.doi.org/10.1108/03074351211226238

Davies, B. (2013). How do boards address risk management and oversight? Journal of Risk Management in Financial Institutions, 6(4), 352 - 365.

Davies, H. (2014). The Dilemna of Defining Risk Appetite in Banking. The Financial Times. Available at: http://www.ft.com/cms/s/0/8363a88c-380c-11e4-a687-00144feabdc0.html\#axzz3gbSy2ygG (Accessed: 29 May 2015).

Davis Polk LLP. (2014a). Risk Governance: Visual memorand um on guidelines proposed by the OCC. Available at: file:///Users/Downloads11.07.14.Risk_Governance_Visual_Memorand um_on_Final_Guidelines_Issued_by_the_OCC\%20(2).pdf (Accesed 4 March 2015). 
Davis Polk. (2014b). US BHCs: Overview of Dodd-Frank Enhanced Prudential Standards Final Rule. Available at: file:///Users/Downloads/Visual.Summary.US_.Bank_.Holding.Companies.Dodd_.Frank_.Enhanced.Prude ntial.Stand ards.pdf (Accessed: 4 March 2015).

de Andres, P. and Vallelado, E. (2008). Corporate governance in banking: The role of the board of directors. Journal of Banking \& Finance, 32 (12), 2570-2580. doi:10.1016/j.jbankfin.2008.05.00

de Haan, J. and Vlahu, R. (2015). Corporate governance of banks: A survey. Journal of Economic Surveys, 00(0), 1 - 50. doi: $10.1111 /$ joes. 12101

de Larosière Report (2009). The high level group on financial supervison in the EU. Available at: http://ec.europa.eu/internal_market/finances/docs/de_larosiere_report_en.pdf. (Accessed: 4 September 2014).

Deloitte. (2014). Risk appetite frameworks: How to spot the geniune article. Available at: http://www2.deloitte.com/uk/en/pages/financial-services/articles/risk-appetite-frameworks.html (Accessed: 10 June 2015).

Deloitte. (2016). A look at board Risk Committee charters of large banks. Available at: https://www2.deloitte.com/content/dam/Deloitte/lu/Documents/financial-services/Banking/lu bankboard-risk-governance.pdf (Accessed: 1 September 2016).

Demirgüc-Kunt, A., and Huizinga, H. (2011). Do we need big banks? Evidence on performance, strategy, and market discipline. Available at: http://papers.ssrn.com/sol3/papers.cfm?abstract id=1774423 (Accessed: 2 October 2015).

Demsetz, R., Saidenberg, M., and Stahan, P. (1997). Agency problems and risk-taking at banks. The Federal Reserve Bank of New York Research. Available at: https://www.newyorkfed.org/medialibrary/media/research/staff reports/sr29.pdf (Accessed: 12 November 2015).

Dermine, J. (2013). Bank Corporate Goverance, Beyond the Global Banking Crisis. Financial Markets, Institutions \& Instruments 22(5): 259 - 281. https://doi.org/10.1111/fmii.12012. 
Dermine, J. and Schoenmaker, D. (2010). In banking, is small beautiful? Financial Markets, Instiutions \& Instruments, 19(1); 1-19. https://doi.org/10.1111/j.1468-0416.2009.00152.x

Dewatripont, M. and Freixas, X. (2012). The Crisis Aftermath: New Regulatory Paradigms. Available at: http://www.voxeu.org/epubs/cepr-reports/crisis-aftermath-new-regulatory-paradigms (Accessed: 29 April 2015).

Devriese, J., Dewatripont, M., Heremans, D., and Nguyen, G. (2004). Corporate Governance, Regulation and Supervision of Banks. Available at https:// core.ac.uk/download/pdf/6233919.pdf?repositoryId=153 (Accessed 12 September 2014).

DeYoung, R. and Rice, T. (2004). How do banks make money? Economic Perspectives: Federal Reserve Bank of Chicago. 4Q,34 - 51. Available at: https://www.chicagofed.org/publications/economicperspectives / 2004/4qtr2004-part3-deyoung-rice + and $\mathrm{cd}=2$ and $\mathrm{hl}=$ enand $\mathrm{ct}=\mathrm{clnkand} \mathrm{gl}=\mathrm{uk}$ (Accessed: 12 July 2014).

Diamond, D. and Rajan, R. (2009). The credit crisis: conjectures about causes and remedies. NBER Working Paper Series. Available at: www.nber.org/papers/w14739 (Accessed: 30 October 2014).

Dietrich, A. and Wanzenried, G. (2011). Determinants of bank profitability before and during the crisis: Evidence from Switzerland. Journal of International Financial Markets, Institutions and Money, 21(3), 307327. doi:10.1016/j.intfin.2010.11.00

Dionne, G. (2013). Risk management, history, definition and critique. Risk management and insurance review, 16(2), 147 - 166. DOI: 10.1111/rmir.12016

Dionne, G., and Triki, T. (2005). Risk management and corporate governance: the importance of independence and financial knoweldge for the board and audit committee. Available at: http://econpapers.repec.org/paper/lvllacicr/0515.htm (Accessed: 14 January 2015).

Dionne, G., and Triki, T. (2013). On risk management determinants: what really matters? The European Journal of Finance, 19(2), 145 - 164. http:/ /dx.doi.org/10.1080/1351847X.2012.664156

Dodd-Frank Act. (2010). The W all Street Reform and Consumer Protection Act of 2010. Available at: https://www.sec.gov/about/laws/wallstreetreform-cpa.pdf (Accessed: 12 October 2015). 
Donaldson, L. and Davis, J.H. (1991). Stewardship Theory or Agency Theory: CEO Governance and Shareholder Returns. Australian Journal of Management, 16 (1), 49-64.

Donaldson, T. and Preston, L. (1995). The Stakeholder Theory of the Corporation: Concepts, Evidence, and Implications. Academy of Management Review, 20(1), 65 - 91.

Dowd, K. (2016). No Stress II. The flaws in the Bank of England Stress Testing Programme. Available at: https://static1.squarespace.com/static/56eddde762cd9413e151ac92/t/579f53b66b8f5ba10895862b/147005 9502224/No+Stress+II (Accessed: 16 August 2016).

EBA. (2011). EBA Guidelines on Internal Governance. Available at: https://www.eba.europa.eu/documents/10180/103861/EBA-BS-2011-116-final-EBA-Guidelines-onInternal-Governance-(2)_1.pdf (Accessed: on 20 June 2015).

EC. (2010). Corporate Governance in Financial Institutions and Remuneration Policies. Available at: http://ec.europa.eu/internal_market/company/docs/modern/com2010_284_en.pdf (Accessed: 14 January 2014).

ECB. (2010a). Beyond ROE: How to measure bank performance. Available at: https://www.ecb.europa.eu/pub/pdf/other/beyondroehowtomeasurebankperformance201009en.pdf (Accessed: 14 January 2015).

ECB. (2010b). Bank Risk During the Financial Crisis - Do Business Models Matter? Available at: https://www.ecb.europa.eu/pub/pdf/scpwps/ecbwp1394.pdf (Accessed: 20 September 2014).

ECB. (2016). SSM supervisory statement on governance and risk appetite. Available at: https://www.bankingsupervision.europa.eu/ecb/pub/pdf/ssm_supervisory_statement_on_governance_and _risk_appetite_201606.en.pdf (Accessed: 18 September 2016).

Ellis, L, Haldane, A., and Moshirian, F. (2014). Systemic risk, governance and global financial stability. Journal of Banking \& Finance, 45(2014), 175 - 181. http://dx.doi.org/10.1016/j.jbankfin.2014.04.02

Ellul, A. and Yerramilli, V. (2013). Stronger Risk Controls, Lower Risk: Evidence from U.S. Bank Holding Companies. The Journal of Finance, 68 (5), 1757-1803. DOI: 10.1111/jofi.1205

Ellul, A. (2015). The Role of Risk Management in Corporate Governance. Annual Review of Financial Economics, $1-17$. 
Elyasiani, E. and Zhang, L. (2015). BHC performance, risk and 'busy' board of directors. Journal of Banking \& Finance, 60(2015), 239 - 251. http://dx.doi.org/10.1016/j.jbankfin.2015.08.02

Erkens, D., Hung, M. and Matos, P. (2012). Corporate governance in the 2007-08 financial crisis: Evidence from financial institutions worldwide. Journal of Corporate Finance, 18(2), 389 -

411. doi:10.1016/j.jcorpfin.2012.01.00

Ernst \& Young. (2013). Remaking financial services: Risk. Management five years after the crisis. Available at: http://www.ey.com/Publication/vwLUAssets/Remaking_financial_services__risk_management_five_years_after_the_crisis_-_Complete/\%24FILE/EY-

Remaking_financial_services_risk_management_five_years_after_the_crisis.pdf (Accessed: 4 January 2015).

Ernst \& Young. (2015). Risk appetite and risk responsibilities. Available at:

http://www.ey.com/Publication/vwLUAssets/ey-risk-governance-2020-risk-appetite-and -riskresponsibilities/\$FILE/ey-risk-governance-2020-risk-appetite-and -risk-responsibilities.pdf (Accessed: 12 December 2015).

Fahlenbrach, R. and Stulz, R. (2011). Bank CEO incentives and the credit crisis. Journal of Financial Economics, 99 (1), 11-26.

Faleye, O., Hoitach, R., and Hoitach, U. (2011). The costs of intense board monitoring. Journal of Financial Economics, 101(2011), $160-181$.

Fama, E. (1980). What's different about banks? Journal of Monetary Economics 15(1), 29 - 39.

Fama, E. and Jensen, M. (1983). Seperatation of owership and control. Journal of Law and Economics XXVI, 1 3.

FDIC. (2018). Bank Failures in Brief. Available at: https://www.fdic.gov/bank/historical/bank/. (Accessed 10 April 2018).

Federal Financial Analytics. (2015). The Consequences of Systemic Regulation for US Regional Banks. Available at: http://www.fedfin.com/ fedfin/images/stories/press_center/Press_Release_PR_080615.pdf (Accessed: 28 April 2016).

Federal Register. (2014a). OCC guidelines establishing heightened standards for certain large insured national banks and federally insured savings associations. 79(176). Available at: 
https://www.federalregister.gov/documents/2015/12/17/2015-31658/guidelines-establishing-stand ardsfor-recovery-planning-by-certain-large-insured-national-banks (Accessed: 16 December 2015).

Federal Register. (2014b). Enhanced Prudential Standards for BHCs and FBOs - Final Rule. 79(59). Available at: https://www.gpo.gov/fdsys/pkg/FR-2014-03-27/pdf/2014-05699.pdf (Accessed: 16 December 2015).

Federal Reserve System Board of Governors. (2016). Largest US BHCs. Available at: http://www.federalreserve.gov/releases/lbr/current/ (Accessed: 27 January 2016).

Fernandes, N. and Fich, E. (2013). Does financial experience belp banks during the credit crisis? Available at: ftp://ftp.cemfi.es/pdf/papers/wshop/WPM\$60DE.pdf (Accessed: 12 September 2014).

Ferrero-Ferrero, I., Fernand ez-Izquierdo, M., and Munoz-Torres, M. (2012). The impact of the board of directors charactertistics on corporate performance and risk-taking before and during the global financial crisis. Review of Managerial Science, 6(3), 207 - 226.

Financial Crisis Inquiry Report (2011). The Final Report of the National Commission on the Causes and fhe Financial and Economic Crisis in the US. Available at: http://www.gpo.gov/fdsys/pkg/GPO-FCIC/pdf/GPO-FCIC.pdf (Accessed: 16 August 2015).

Fischer, E. (2015). Evolving Governance Realiities for Financial Institutions: The Likely Impact of OCC's Heightened Expectations Guidelines on Bank Directors. Available at: www.bu.edu/bucflp/.../2015/04/PRESENTATION-FOR-NC 2.3.2015 (Accessed: 20 December 2015).

Fleischer, A., Hazard, G., and Klipper, M. (1988). Board Games. Boston: Little Brown \& Co.

Fogel, K., Ma, L, and Morck, R. 2014. Powerful Indpendent Directors. Available at: https://papers.sstn.com/sol3/papers.cfm?abstract id=2377106 (Accessed: 30 September 2015).

Fonseca, A. and González, F. (2007). Cross-country determinants of bank income smoothing by managing loan loss provisions. Journal of Banking \& Finance, 217-228. doi:10.1016/j.jbankfin.2007.02.01

Fox, C., Bugalla, J., and Narvaez, K. (2011). An evolving model for board risk governance. Risk, and Insurance Management Society, Available at: https://www.rims.org/resources/ERM/Documents/RiskGovernance web.pdf (Accessed: 13 September 2014). 
FSB. (2013). Thematic Review on Risk Governance. Available at:

http://www.financialstabilityboard.org/2013/02/r_130212/ (Accessed: 1 July 2015).

G30 - The Group of Thirty. (2012).Toward effective governance of financial institutions. Available at:

http://www.group30.org/images/PDF/TowardEffGov.pdf (Accessed: 5 June 2015).

G30 - The Group of Thirty. (2015). Banking Conduct and Culture. Available at:

http://group30.org/rpt_67.shtml (Accessed: 12 October 2015).

Gao, Y., Liao, S., and Wang, X. (2013). The Economic Impact of the Dodd-Frank Act upon SIFIs: Evidence from

Market Reactions. Available at: file:///Users//Downloads/SSRN-id1919630\%20(1).pdf (Accessed: 10 August 2016).

Giroud, X. and Mueller, H. (2010). Does corporate governance matter in competitive industries? Journal of Financial Economics, 95(3), 312-331.

Gontarek, W. (2016). Risk governance of financial institutions: the growing importance of risk appetite and culture. Journal of Risk Management in Financial Institutions, 9(2), 120 - 129.

Gontarek, W. and Bender, R. (2018). Examining risk governance practices in global financial institutions: The adoption of risk appetite statements. Journal of Banking Regulation, 1-12. DOI: 10.1057/s41261-018-0067-2.

Grant Thornton. (2014). OCC's risk governance guidelines go beyond heightened expectations. Available at: http://www.grantthornton.com/ /media/content-page-files/financial-services/pdfs/2015/OCC-RiskGovernance-Guidelines-Feb2015.ashx (Accessed: 13 September 2015).

Greenspan, A. (1996). Remarks at the Financial Markets Conference of the Federal Reserve Bank of Atlanta. Coral Gables, Florida. February 23rd 1996. https://fraser.stlouisfed.org/scribd/?item_id=8561and filepath=/docs/historical/greenspan/Greenspan_19960223.pdf (Accessed: 1 October 2016).

Greuning, H. and Bratanovic, S. (2003). Analyzing and Managing Banking Risk: A Framework for Assessing Corporate Governance and Financial Risk. Washington DC: IBRD Publication.

Gropp, R., and Köhler, M. (2010). Bank owners or bank managers: who is keen on risk? Evidence from the financial crisis. Center for European Economic Research. Available at: http://hdl.hand le.net/10419/30179 (Accessed: 4 January 2015). 
Grove, H., and Cook, T. (2013). Lehman Brothers and Bear Stearns: Any Financial and Corporate Governance Differences? Amity Global Business Review, (1), 113 - 130. DOI:10.22495/cocv11i1c6art7

Grove, H., Patelli, L., Victoravich, L. and Xu, P. (2011). Corporate Governance and Performance in the Wake of the Financial Crisis: Evidence from US Commercial Banks. Corporate Governance: An International Review, 19(5), 418-436. https://doi.org/10.1111/j.1467-8683.2011.00882.x

Gulamhussen, M., and Santa, S. (2015). Female directors in bank boardrooms and their influence on performance and risk-taking. Global Finance Journal, 28(2015), 10 -

23. http://dx.doi.org/10.1016/j.gfj.2015.11.002

Guo, R., Langston, V., and Hadley, L. (2001). Business Cycle, Corporate Governance, and Bank Performance. Research in Business and Economics Journal, (2), 1 - 11.

Hagendorff, J. (2014). Corproate governance in banking in Oxford Handbook of Banking. Oxford: Oxford University Press.

Hagendorff, J. and Vallascas, F. (2011). CEO Pay Incentives and Risk-taking: Evidence from Bank Acquisitions. Journal of Corporate Finance, 17(4), 854 - 870. DOI:

10.1016/j.jcorpfin.2011.04.009

Hahn, P. and Lasfer, M. (2016). Impact of foreign directors on board meetings frequency. International Review of Financial Analysis, 40(2016), 295 - 308. doi: 10.1016/j.irfa.2015.11.004

Hambrick, D. and Mason, P. (1984). Upper echelons: The organization as a reflection of its top managers. Academy of Management Review, 9, 193 - 206.

Hayes, N. (2013). Governance for strengthened risk management. RMA Journal, 95(8), 23 - 25.

Hermalin, B. and Weisbach, M. (2003). Boards Of Directors As An Endogenously Determined Institution: A Survey Of The Economic Literature. Economic Policy Review, 9(1), 7-20. 
Hines, C. and Peters, G. (2015). Voluntary risk management committee formation: Determinants and shortterm outcomes, Journal of Accounting and Public Policy, 34(2015), 267 -

291. http://dx.doi.org/10.1016/j.jaccpubpol.2015.02.001

Hines, C., Masli, A, Mauldin, E., and Peters, G. (2015). Board Risk Committees and audit pricing. Auditing: A Journal of Practice and Theory, 34(4), 59 -84. DOI: 10.2308/ajpt-51035

Holmquist, E. (2014). Why you need a Risk Committee. RMA Journal, 96, 18 - 21.

Hopt, K. (2013). Corporate governance of banks and other financial institutions after the financial crisis regulation of light of empiry and theory. Available at: http://papers.ssrn.com/sol3/papers.cfm?abstract_id=2334874 (Accessed: 12 October 2015).

Hoyt, R., and Liebenberg, A. (2011). The value of enterprise management. Journal of Risk and Insurance, 78(4), 795 - 822. DOI: 10.1111/j.1539-6975.2011.01413.x

IIF. (2011). Implementing Robust Risk. Appetite Frameworks to Strengthen Financial Institutions. Available at: file:///Users/ /Downloads/riskappetitereportfinal.single1.pdf (Accessed: 2 June 2015).

IIF. (2018). IIF Global Debt Monitor. Available at: https://www.iif.com/publications/global-debt-monitor. Accessed 11 April 2018.

IMF. (2014). Risk-taking by Banks: The role of governance and executive pay (IMF). Available at: https://www.imf.org/external/pubs/ft/gfsr/2014/02/pdf/c3.pdf (Accessed: 3 January 2015).

Iqbal, J., Strobl, S., and Vähämaa, S. (2015). Corporate Governance and the Systemic Risk of Financial Institutions. Available at: http://papers.ssrn.com/sol3/papers.cfm?abstract id=2485329 (Accessed: 28 September 2016). Iselin, M. (2016). Estimating the potential impact of requiring a stand-alone board level Risk Committee.

Available at: http://papers.ssrn.com/sol3/papers.cfm?abstract_id=2761556 (Accessed: 15 August 2016). Ivantsov, E. (2013). Heads or Tails. London: Routledge.

Jackson, P. (2014). Risk culture and effective risk governance. London: Incisive Media. Jensen, M. (1993). The modern industrial revolution: Exit and failure of internal control systems. Journal of Finance, 48(3), $831-880$.

Jensen, W. and Meckling, W. (1976). Theory of the firm: Managerial behaviour, agency costst and ownership structure. Journal of Financial Economics, 3(4), 305-360. 
John, K. and Senbet, L. (1998). Corporate governance and board effectiveness. Journal of Banking \& Finance, 22(1998), 371-403.

Kanagaretnam, K. and Lobo, G. (2003). Managerial incentives for income smoothing through bank loan loss provisioning. Review of Quantitative Finance and Accounting, 5: 1 - 29.

Kanagaretnam, K. Lobo, G. and Yang, D. (2005). Determinants of signalling by banks through loan loss provisions. Journal of Business Research, 58(2005), 312 - 320.

Kashyap, A., Rajan, R. and Stein, J. (2008). Re-thinking capital regulation. Available at: http://scholar.harvard.edu/stein/publications/rethinking-capital-regulation (Accessed: 30 April 2015).

Kashyap, A. (2010). Lessons from the Financial Crisis for Risk Management: A Paper Prepared for the Financial Crisis Inquiry Commission. Available at: http://faculty.chicagobooth.edu/anil.kashyap/research/papers/lesson for fcic.pdf (Accessed: 13 September 2014).

Kumar, N. \& Singh, N. (2013). Global Financial Crisis: Corporate Governance Failures and Lessons Learned. Journal of Finance, Accounting and Management, 4(1), 21 - 34.

Kupiec, P. and Lee, Y. (2012). What factors explain differences in return on assets amoung community banks? FDIC Publications. 1-16.

Laeven, L. (2013). What's special about banks? Annual Review of Financial Economics, 5(1), 63 - 92.

Laeven, L. and Levine, R. (2009). Bank Governance, regulation and risk-taking. Journal of Financial Economics, $00(0000), 2-43$.

Lam, J. and Potter, S. (2012). In search of risk experts for bank boards. RMA Journal, 94(8), 17 - 21.

Lang, W. and Jagtiani, J. (2010). The mortgage and financial crises: the role of credit risk management and coroprate governance. Atlantic Economic Journal, 38, 295 - 316. DOI 10.1007/s11293-010-9221-7

Lechner, M. (2010). The Estimation of Causal Effects by Difference in Difference Methods, Foundations and Trends in Econometrics, 4(3), 165 - 224. DOI: 10.1561/0800000014

Lee, K. and Kwok, C. (1988). Multi-national corporations versus domestic corporations: International environmental factors and determinants of capital structure. Journal of International Business Studies, 19, 195-217. 
Levine, R. (2004). The Corporate Governance of Banks: A Concise Discussion of Concepts and Evidence. Available at: https://openknowledge.worldbank.org/bitstream/hand le/10986/14239/WPS3404.pdf?sequence=1 (Accessed: 3 January 2015).

Levine, R. (2012). The Governance of Financial Regulation: Reform Lessons from the Recent Crisis. International Review of Finance. 12 (1), 39-56. DOI: 10.1111/j.1468-2443.2011.01133.x

Lingel, a and Sheedy, E. (2012). The Influence of Risk Governance on Risk Outcomes -International Evidence. Available at: :http://papers.ssrn.com/sol3/papers.cfm?abstract_id=2482168 (Accessed: 28 February 2015).

Love, I. (2011). Corporate Governance Around the World: What We Know and What We Don't, World Bank Research Observer, 26(1), $42-70$.

Luttrell, D., Atkinson, T., and Rosenblum, H. (2013). Assessing the costs and consequences of the 2007 2009 financial crisis and its aftermath. Economic Letter: Federal Reserve Bank of Dallas. Available at: http://www.dallasfed.org/research/eclett/2013/el1307.cfm (Accessed: 30 August 2015).

Maati, J. and Maati-Sauvez, C. (2012). Regulatory Governance Mechanisms in Banks. Bankers, Markets and Investors, No. 119 (August), 43-59.

Macey, J, and O'Hara, M, (2003). The Corporate Governance of Banks. FRBNY Economic Policy Review, (April), 91-107.

Macey, J. and O’Hara, M. (2016). Bank Corporate Governance: A Proposal for the Post-Crisis World. FRBNY Economic Policy Review, August: 85 - 105.

Madison, G., Gregory, C. Friesen, C. and Horner, N. (2015). International Banking Requlators Propose Revised Corporate Governance Principles: Reinforce Board Responsbilites for Risk Oversight and Governance Culture. Journal of Taxation and Regulation of Financial Institutions, 28(4): 51 - 55.

Mamatzakis, E. and Bermpei, T. (2015). The Effect of Corporate Governance on the Performance of US Investment Banks. Financial Markets, Institutions \& Instruments, 24: 191-239. https://doi.org/10.1111/fmii.12028. 
MAS - The Monetary Authority of Singapore. (2013). Guidelines on corporate governance -Singapore. Available at: http://www.mas.gov.sg/ / media/resource/legislation guidelines/banks/guidelines/Corporate\%20Governa nce\%20Guidelines 2013.pdf (Accessed: 13 September 2013).

McConnell, P. (2012). The governance of strategic risks in systemically important banks. Journal of Risk Management in Financial Institutions, 5(2), 128 - 142.

McConnell, P. (2016). Strategic risk management: The failure of HBOS and its regulators. Journal of Risk Management in Financial Institutions, 9(2), 147 - 162.

McNulty, J. and Akhighbe, A. (2015). Corporate culture, financial stability and bank litigation. Available at: https://www.newyorkfed.org/medialibrary/media/research/conference/2015/econ_culture/McNulty_Corp orateCultureand FinancialStability.pdf (Accessed: 22 December 2015).

McNulty, T., Florackis, C. and Ormrod, P. (2013). Boards of Directors and Financial Risk during the Credit Crisis. Corporate Governance: An International Review, 21(1), 58-78.

Mehran, H., Morrison, A. and Shapiro, J. (2011). Corporate Governance and Banks: What Have We Learned from the Financial Crisis? NY Federal Board Reports. Available at: http://www.newyorkfed.org/research/staff_reports/sr502.pdf (Accessed: 4 January 2015).

Merton, R. (1974). On the pricing of corporate debt: The risk structure of interest rates. Journal of Finance, 29 , $449-470$.

Mikels, J. and Reed, A. (2009). Monetary losses do not loom large in later life: Age differences in the framing effect, Journal of Gerontology. Psychological Sciences, 64B(4), 457-460.

Mikes, A. (2010). Becoming the Lamp Bearer: The Emerging Role of the CRO. In Enterprise Risk Management. Fraser, J. and Simkins, B. London: Wiley \& Sons.

Mikes, A. (2008). CROs at crunch time: Compliance champions or business partners? Journal of Risk Management in Financial Institutions, 2(1), 7 - 25.

Mikes, A. (2014). The Triumph of the Humble CRO. Harvard Business School Working Paper 14(114): 1 - 23. Available at: http://www.hbs.edu/faculty/Publication\%20Files/14-114 60866b77-6b5c-4fd3-9ce1e2ab8d5da654.pdf (Accessed: 10 January 2015). 
Minton, B., Taillard, J. and Williamson, R. (2014). Do Independence and Financial Expertise of the Board Matter for Risk-taking and Performance? Journal of Financial and Quantitative Analysis, 49(2), 1 -

66. doi:10.1017/S0022109014000283

Mollah, S. and Liljeblom, E. (2016). Governance and bank characteristics in the credit and sovereign debt crisis - the impact of CEO power. Journal of Financial Stability, 27(2016), 59 -

73. http://dx.doi.org/10.1016/j.jfs.2016.09.003

Mongiardino, A. and Plath, C. (2010). Risk governance at large banks : Have any lessons been learned? Journal of Risk Management in Financial Institutions, 3(2), 116 - 123.

Moody's. (2005). Don't bet on strong governance: Observations on corporate governance in US banks, New York: Moody’s Special Comment Series.

Mülbert, P. (2010). Corporate Governance of Banks after the Financial Crisis-Theory, Evidence, Reforms. Available at: http://papers.ssrn.com/sol3/papers.cfm?abstract_id=1448118 (Accessed: 4 January 2015).

Mullineux, A. (2006). The corporate governance of banks. Journal of Financial Regulation and Compliance, 14(4), $375-382$.

Nestor. (2010). Bank Boards after the Flood. The Changing Governance of the 25 Largest European Banks. Available at: http://www.nestoradvisors.com/publications (Accessed: 11 November 2014).

Nguyen, D., Hagendorff, J., and Eshraghi, A. (2015). Which executive characteristics create value in banking? Evidence from appointment announcements. Corporate Governance: An International Review, 23(2), 112 128. doi:10.1111/corg.12084

Oliver Wyman. (2013). Defining your risk appetite. The importance of taking a qualitative and quantitative approach. Available at: https://www.google.co.uk/\#q=Oliver+Wyman.+(2013)

+ Defining + your + risk + appetite. + The + importance + of + taking $+a+$ qualitative + and + quantitative + approach

(Accessed: 3 September 2014).

OSFI. (2013). Canadian bank regulator: Sound Business and Financial Practices. Available at: www.Osfi.bsif.gc.ca (Accessed: 3 September 2013).

Palvia, A. (2011). Banks and managerial discipline: Does regulatory monitoring play a role? The Quarterly Review of Economics and Finance, 51(2011), 56-68. doi:10.1016/j.qref.2010.10.003 
Pathan, S. (2009). Strong boards, CEO Power and bank risk-taking. Journal of Banking \& Finance, 33(7), 13401350. doi:10.1016/j.jbankfin.2009.02.00

Pathan, S. and Skully, M. (2010). Endogenously structured boards of directors in banks. Journal of Banking \& Finance, 34(2010), 1590 - 1606. doi:10.1016/j.jbankfin.2010.03.00

Pathan, S. and Faff, R. (2013). Does board structure in banks really affect their performance?, Journal of Banking \& Finance, 37(2013), 1573 - 1589. http://dx.doi.org/10.1016/j.jbankfin.2012.12.01

Peni, E. and Vähämaa, S. (2012). Did good corporate governance improvide bank performance during the financial crisis? Journal of Financial Services Research, 41, 19 - 35. DOI 10.1007/s10693-011-0108-9

Peni, E., Smith, S., and Vähämma, S. (2013). Bank corproate governance and real estate lending during the financial crisis. Journal of Real Estate Research, 35(3), 313- 343.

Pi, L. and Timme, S. (1993). Corporate control and bank efficiency. Journal of Banking \& Finance, 17(2-3), 515530.

Pirson, M. and Turnbull, S. (2011). Corporate governance, risk management, and the financial crisis: An information processing view. Corporate Governance: An International Review, 19(5), 459 - 470. doi:10.1111/j.14678683.2011.00860.x

Prager, J. (2013). The Financial Crisis of 2007/2008: Misaligned Incentives, Bank Mismanagement, and Troubling Policy Implications. Economics, Management and Financial Markets, 8(2), 11 - 56.

Rajan, R. (2005). Has financial development made the world riskier? National Bureau of Economic Research, 11(728), $313-369$.

Roman, R. (2015). Three Essays in Banking: Corprorate Governance, Internationalization and Government Bailouts. Available at: http://scholarcommons.sc.edu/etd/3104 (Accessed: 27 January 2016).

Sabato, G. (2009). Financial Crisis: Where did Risk Management Fail? International Review of Applied Financial Issues and Economics, 2(2), $316-327$.

Saunders, A., Strock, E., and Travlos, N. (1990). Ownership Structure, Deregulation and Bank Risk Taking. The Journal of Finance, XLV(2), 643-654.

Saunders, A. and Cornett, M. (2018). Finanical Instiutions Management: A Risk Management Approach, 9 th $^{\text {edition, }}$ McGraw-Hill: New York, NY. 
SSG. (2008). Observations on risk management practices during the recent market turbulence. Available at: https://www.sec.gov/news/press/2008/report030608.pdf (Accessed: 15 January 2015).

SSG. (2009). Risk Management Lessons from the Global Banking Crisis of 2008. Available at: https://www.sec.gov/news/press/2009/report102109.pdf (Accessed: 15 January 2015).

SSG. (2010). Observations on Developments in Risk. Appetite Frameworks and IT Infrastructure. Available at: http://www.newyorkfed.org/newsevents/news//2010/an101223.html (Accessed: 20 June 2015).

Stefanelli, V. and Cotugno, M. (2011). An Emprical Analysis on Board Monitoring Role and Loan Portfolio Quality Measurement in Banks. Munich Personal RePEC Archive. Available at: http://mpra.ub.muechen.de/19766 (Accessed 10 September 2014).

Stulz, R. (2008). Risk Management Failures: What are they and when do they happen? Journal of Applied Corporate Finance, 20(4), $58-67$.

Stulz, R. (2015). Risk-Taking and Risk Management by Banks. Journal of Applied Corporate Finance, 27(1), 8 - 16. Switzer, L. and Wang, J. (2013). Default Risk Estimation, Bank Credit Risk, and Corporate Governance. Financial Markets, Institutions and Instruments, 22(2): 91 -112. https://doi.org/10.1111/fmii.12005

Tao, N. and Hutchinson, M. (2013). Corporate governance and risk management: The role of risk management and compensation committees. Journal of Contemporary Accounting and Finance, 9(2013), 83 99. http://dx.doi.org/10.1016/j.jcae.2013.03.003

United Nations. (2010). Corporate Governance in the Wake of the Financial Crisis. Available at: http://www.unctaddocs.org/files/CG-in-Wake-of-Fin-Crisis-Full-Report.pdf (Accessed: 12 October 2015 ).

Upadhyay, A., Bhargava, R., and Faircloth, S. (2014). Board structure and the role of monitoring committees. Journal of Business Research, 67(2014), 1486 - 1492. http://dx.doi.org/10.1016/j.jbusres.2013.07.017

Vafeas, N. (1999). Board meeting frequency and firm performance, board dynamics and the influence of professional background, gender and ethic diversity of directors. Journal of Financial Economics, 53: 113 - 142. Vafeas, N. (2003). Length of board tenure and outside director independence. Journal of Business Finance and Accounting, 30(7-8), 1043 - 1064. 
Vallascas, F., Mollah, S., and Keasey, K. (2017). Does the impact of board independence on large banks change after the financial crisis? Journal of Corporate Finance, 44(2017), 149-166.

https://doi.org/10.1016/j.jcorpfin.2017.03.011

van Dijk, M. (2013). The Social Costs of Financial Crisis. Available at:

http://static1.squarespace.com/static/531afe04e4b0b17f973f5962/t/531b78cfe4b0c205411e3e6a/13943093

27547/The+social+costs+of+financial+crises+-+Mathijs+van+Dijk+-+SSRN+13June2013.pdf (Accessed: 15 August 2015).

Vyas, D. (2012). The timeliness of accounting writedowns by US finanical institutions during the crisis of 2007 - 2008. Journal of Accounting Research, 49(3), 823 - 860. DOI: 10.1111/j.1475-679X.2011.00410.x

Wahlen, J. (1994). The nature of information in commercial bank loan loss disclosures. The Accounting Review, $455-478$.

Walker, D. (2009). A review of corporate governance in UK banks. Available at: http://webarchive.nationalarchives.gov.uk/+/http:/www.hm-treasury.gov.uk/d/walker_review_261109.pdf (Accessed: 3 January 2015).

Wang, W., Lu, W., and Lin, Y. (2012). Does corporate governance play an important role in BHC performance? Evidence from the US. Economic Modelling, 29(2012), 751 760. doi:10.1016/j.econmod.2012.01.021

Woo, V., Chelluboina, B, and Xoual, W. (2014). The effectivenss of the regulatory stress testing disclosure process. Financial Markets, Institutions \& Instruments, 23(1), 1 - 67. https://doi.org/10.1111/fmii.12014

Wooldridge, J. (2001). Econometric Analysis of Cross Section and Panel Data. Cambridge: The MIT Press.

Wymeersch E. (2012). Risk if Financial Institutions - is it managed? Available at: http:// ssrn.com/abstract=1988926 (Accessed: 4 January 2015).

Xu, T., Grove, H. and Schaberl, P. (2013). Corporate governance: A risk management approach. Corporate Ownership and Control, 10(2), $104-114$. 
Yeh, Y., Chung, H., and Liu, C. (2011). Committee Independence and Financial Institution Performance during the 2007-08 Credit Crunch: Evidence from a Multi-Country Study. Corporate Governance: An International Review, 19(5), 437 - 458. doi:10.1111/j.1467-8683.2011.00884.x

Yoost, D. (2014). Board oversight of the risk appetite framework. RMA Journal, May: 44 - 51.

Zagorchev, A., and Gao, L. (2015). Corporate governance and performance of financial institutions. Journal of Economics and Business, 82(2015), 17 - 41.

Zhang, H. (2015). Instructions and Guide for Credit Rating. Available at: https://data.bloomberglp.com/bat/sites/3/Paul-Laux-Lab-6.pdf (Accessed: 3 January 2015).

Zhang, Z., Lu, X., and Xie, L. (2014). Determinants of financial distress in US large BHCs. Contemporary Economic Policy, 34(2), $250-267$.

Zhou, X. (2001). Understanding determinants of managerial ownership and the link between ownership and performance. Journal of Financial Economics, 25: 2015 - 2040. 


\section{NOTES ON THE CONTRIBUTORS AND ACKNOWLEDGEMENTS}

Corresponding Author: Walter Gontarek, Cranfield University. Email:

walter.gontarek@,cranfield.ac.uk.

Walter Gontarek is the CEO of Channel Capital Advisors, a London-based FCA authorised and regulated investment firm. He is a visiting fellow at Cranfield University where he lectures on financial markets, regulation, corporate governance and ethics as well as FinTech markets. He has served as an independent non-executive board director for FrontClear Management BV, Wiserfunding Ltd. and Cloud 9 Group. Walt previously served as Global Head and Managing Director of the global credit products business at the Royal Bank of Canada. Walt also served as president of a retail banking platform in the US. He holds a BBA (Finance) from Loyola University, an MBA (Finance) from the NYU Stern School of Business, and a Doctorate in Finance from Cranfield University, where his thesis focused on risk governance. He was named a Financial Expert at PRIME in The Hague in 2012 and is an academic member of the ECGI and the ICGS.

Yacine Belghitar is a Professor of Finance at Cranfield University. Prior to coming to Cranfield School of Management, Yacine taught and completed research at Middlesex and Durham Universities. He held the positions of Research Leader for the group of accounting and finance and Director of the MSc in Finance. He has successfully supervised and externally examined several doctoral students. He is an independent advisor on corporate strategy and risk management and has also worked for a large Middle Eastern oil and gas company. He has published extensively and his papers have appeared in top international academic journals such as Economic Journal, Journal of Financial Research, Journal of Banking \& Finance, and Small Business Economics. Yacine is currently serving as the associate editor of Frontiers in Finance and Economics Journal. 
We would like to thank a number of colleagues and friends that contributed to our research. Many thanks to Professor Ed Altman of NYU Stern for his meaningful comments and input into our research. We thank Dr Stijn Claessens, currently Head of Financial Stability Policy at the BIS, for his comments on various drafts of this research and his focus on the channels of BHC outcomes. We thank Visiting Associate Professor Jérôme Taillard (currently at the Wharton School and Babson College) for his input and comments regarding alternative regulatory-driven explanations of performance and risk-taking determinants. We thank Dr Gabriele Sabato, a senior practitioner in risk appetite frameworks and now CEO of Wiserfunding Ltd for his comments on risk appetite practices. We also thank Professor Meziane Lasfer of the Cass Business School, Dr Vitali Avagyan of University of Edinburgh, and both Dr Ruth Bender and Dr Joe Nellis of Cranfield University for their input into earlier versions of this research.

Various practitioners of risk governance are also gratefully acknowledged for their input including Morten Friis of RBC and RBS, Eusebio Garre of IADB Group, JH van Dijk of FrontClear, Suzanne Labarge of McMaster University and Bank of China, Jeffery Weaver of Key Bank and Chairman Emeritus of the IACPM Board of Directors, Bruce MacLaren of RBC, Ronald Blok previously of Rabobank, Phil Sullivan and Alok Kumar (each of Channel Capital). We also thank participants at recent conferences with whom we could refine our research approach, including the $10^{\text {th }}$ annual International Risk Management Conference (IRMC 2017) held in Florence, Italy sponsored by NYU Stern/University of Florence/University of Udine and the Risk, Banking \& Finance Society, and the International Corporate Governance Society Conference (ICGS 2016) held at the Geneen Institute, Bentley University. We are also grateful for practitioner input relating to risk appetite at the Institute for Regulation and Ethics associated with the G30 report on conduct at Clothworker's Hall in London in 2016. Lastly, we thank the reviewers for their valuable comments. 


\section{APPENDICES}

\section{Appendix 1: List of BHCs}

\begin{tabular}{|c|c|}
\hline \# & BHC Name \\
\hline 1 & JP MORGAN CHASE \& CO \\
\hline 2 & BANK OF AMERICA CORP \\
\hline 3 & WELLS FARGO \& CO \\
\hline 4 & CITIGROUP INC \\
\hline 5 & US BANCORP INC \\
\hline 6 & PNC FINANCIAL SERVICES INC \\
\hline 7 & BANK OF NEW YORK MELLON \\
\hline 8 & STATE STREET CORP \\
\hline 9 & CAPITAL ONE FINANCIAL CORP \\
\hline 10 & SUNTRUST BANKS INC \\
\hline 11 & BB\&T CORP \\
\hline 12 & AMERICAN EXPRESS CORP \\
\hline 13 & FIFTH THIRD CORP \\
\hline 14 & GOLDMAN SACHS GROUP INC \\
\hline 15 & MORGAN STANLEY \\
\hline 16 & REGIONS FINANCIAL CORP \\
\hline 17 & NORTHERN TRUST CORP \\
\hline 18 & ALLY FINANCIAL CORP \\
\hline 19 & M\&T BANK CORP \\
\hline 20 & KEYCORP \\
\hline 21 & DISCOVER FINANCIAL SERVICES \\
\hline 22 & COMERICA INC \\
\hline 23 & HUNTINGTON BANCSHARES \\
\hline 24 & FIRST REPUBLIC BANK \\
\hline 25 & FIRST NIAGARA FINANCIAL GRP \\
\hline 26 & SVB FINANCIAL GROUP \\
\hline 27 & PEOPLES UNITED FINANCIAL INC \\
\hline 28 & CITY NATIONAL CORP \\
\hline 29 & KEYCORP \\
\hline 30 & BOK FINANCIAL CORP \\
\hline 31 & EAST WEST BANCORP \\
\hline 32 & SIGNATURE BANK \\
\hline 33 & CULLEN/FROST BANKERS INC \\
\hline 34 & SYNOVUS FINANCIAL CORP \\
\hline 35 & ASSOCIATED BANC-CORP \\
\hline 36 & FIRST HORIZON NATIONAL CORP \\
\hline 37 & FIRSTMERIT CORP \\
\hline 38 & UMPQUA HOLDINGS CORP \\
\hline 39 & PROSPERITY BANCSHARES INC \\
\hline 40 & CIT GROUP \\
\hline 41 & HANCOCK HOLDING CO \\
\hline 42 & TCF FINANCIAL CORP \\
\hline 43 & BANKUNITED INC \\
\hline 44 & ZIONS BANCORPORATION \\
\hline 45 & VALLEY NATIONAL BANCORP \\
\hline 46 & SUSQUEHANNA BANCSHARES \\
\hline
\end{tabular}

\begin{tabular}{|c|c|}
\hline \# & BHC Name \\
\hline 47 & TEXAS CAPITAL BANCSHARES \\
\hline 48 & PACWEST BANCORP \\
\hline 49 & UMB FINANCIAL CORP \\
\hline 50 & PRIVATEBANCORP INC \\
\hline 51 & IBERIA BANCORP \\
\hline 52 & F N B CORP \\
\hline 53 & BANK OF HAWAII CORP \\
\hline 54 & ASTORIA FINANCIAL CORP \\
\hline 55 & WASHINGTON FED INC \\
\hline 56 & MB FINANCIAL INC/MD \\
\hline 57 & RAYMOND JAMES FNCL \\
\hline 58 & BANCORPSOUTH INC \\
\hline 59 & FLAGSTAR BANCORP INC \\
\hline 60 & TRUSTMARK CORP \\
\hline 61 & CATHAY GENERAL BANCORP \\
\hline 62 & OLD NATIONAL BANCORP \\
\hline 63 & WESTERN ALLIANCE BANC \\
\hline 64 & INTL BANCSHARES CORP \\
\hline 65 & CAPITOL FEDERAL FINANCIAL \\
\hline 66 & FULTON FINANCIAL CORP \\
\hline 67 & NATIONAL PENN BANCSHARE \\
\hline 68 & PROVIDENT FINANCIAL SVSC \\
\hline 69 & COLUMBIA BANKING SYSTEM \\
\hline 70 & FIRST INTERSTATE BANCSYS \\
\hline 71 & GLACIER BANCORP, INC. \\
\hline 72 & NBT BANCORP INC \\
\hline 73 & STERLING BANCORP \\
\hline 74 & UNITED COMMUNITY BANKS \\
\hline 75 & COMMUNITY BANK SYSTEM \\
\hline 76 & CHEMICAL FINANCIAL CORP \\
\hline 77 & HOME BANCSHARES, INC. \\
\hline 78 & CVB FINANCIAL CORP \\
\hline 79 & UNION BANKSHARES CORP \\
\hline 80 & BBCN BANCORP INC \\
\hline 81 & PARK NATIONAL CORP \\
\hline 82 & FIRST FINANCIAL BANCORP \\
\hline 83 & CUSTOMERS BC \\
\hline 84 & CAPITAL BK FNCL CORP \\
\hline 85 & INDEPENDENT BANK Corp \\
\hline 86 & POPULAR INC \\
\hline 87 & BOSTON PRIVATE FINL \\
\hline 88 & BANCFIRST CORP \\
\hline 89 & BERKSHIRE HILLS BANCORP \\
\hline 90 & LEGACYTEXAS FNCL GRP \\
\hline 91 & FIRST COMMONWLTH FINL \\
\hline 92 & PINNACLE FNCL PTNR \\
\hline
\end{tabular}

BHC Name

FIRST FNCL BSHRS

First Bank

RENASANT CORP

FIRST MERCHANTS CORP

TOWNEBANK

OPUS BK

EAGLE BANCORP, INC

TALMER BANCORP INC.

UNITED BANKSHARES INC/WV

STIFEL FNCL CORP

FLUSHING FC

WESTAMERICA BANC CORP

NATIONAL BK HOLDS CORP

$S \& T$ BANCORP INC

BANNER CORP

CENTRAL PACIFIC FINANCIAL

BANCORP

1ST SOURCE CORP

SIMMONS FIRST NAT CORP

TRUSTCO BANK CORP/NY

WILSHIRE BANCORP INC.

SANDY SPRING BANCORP INC.

SERVISFIRST BANCSHARES

NEW YORK CMNTY BANCORP

YADKIN FINANCIAL CORP

BNC BANCORP

AMERIS BANCORP

HANMI FIN CORP

GREAT SOUTHERN BANCORP

FIRST NBC BHC

REPUBLIC BANCORP

TRICO BANCSHARES

CENTERSTATE BANKS INC.

FIRST BUSEY CORP

CENTURY BANCORP INC

COMMUNITY TR BANCORP INC

AKELAND BANCORP INC

WASHINGTON TR BC INC

HERITAGE FC

CARDINAL FC

FIDELITY SOUTHERN CORP

WINTRUST FINANCIAL CORP

DIME COMMUNITY BANCS

MAINSOURCE FNCL GRP

COBIZ FNCL INC

BRYN MAWR BK CORP

BANK MUTUAL CORP

Source: Author, based on US Federal Reserve data (http://www.federalreserve.gov/releases/lbr/current/) 


\section{Appendix 2: Variable Definitions}

\begin{tabular}{|c|c|c|c|}
\hline No. & Name & $\begin{array}{l}\text { Type of } \\
\text { Variable }\end{array}$ & Notes \\
\hline 1. & BHC Assets & Explanatory & $\begin{array}{l}\text { USD value (log) of BHC assets from the US Federal Reserve Bank website for } \\
\text { each year-end reporting period. }\end{array}$ \\
\hline 2. & $\begin{array}{l}\text { BOD meetings } \\
\text { Number }\end{array}$ & Explanatory & $\begin{array}{l}\text { Number of board meetings held within that year, a proxy for board monitoring, } \\
\text { collected from BoardEx. }\end{array}$ \\
\hline 3. & $\begin{array}{l}\text { BOD Non-inside } \\
\text { Directors } \\
\text { percentage }\end{array}$ & Explanatory & $\begin{array}{l}\text { Percentage of supervisory directors, as published by BoardEx, denoting directors } \\
\text { who are not currently affiliated with management; also referred to as non-inside } \\
\text { directors. }\end{array}$ \\
\hline 4. & Deposits \% & Explanatory & Measured as total deposits divided by total assets as collected from Bloomberg. \\
\hline 5. & HPR & Dependent & $\begin{array}{l}\text { BHCs' annual holding period returns (HPR) is collected from Bloomberg and } \\
\text { assumes dividends re-invested in equity securities. }\end{array}$ \\
\hline 6. & $\begin{array}{l}\text { Institutional } \\
\text { shareholding \% }\end{array}$ & Explanatory & Percentage of shareholding by institutional investors collected from Bloomberg. \\
\hline 7. & $\begin{array}{l}\text { International } \\
\text { activities } \%\end{array}$ & Explanatory & $\begin{array}{l}\text { Percentage of non-domestic revenue for each BHC collected from Bloomberg and } \\
\text { used in risk-related outcome estimations. }\end{array}$ \\
\hline 8. & $\begin{array}{l}\text { Loan loss } \\
\text { provisions } \%\end{array}$ & & $\begin{array}{l}\text { Loan loss provisions (LLP) is measured as the total loan loss provision divided by } \\
\text { total assets and is collected via Bloomberg (Kanagartnam \& Lobo, 2003; Zagorchev } \\
\text { \& Gao, 2015). }\end{array}$ \\
\hline 9. & $\begin{array}{l}\text { Other Operating } \\
\text { Income } \%\end{array}$ & Explanatory & $\begin{array}{l}\text { Income not generated from the ordinary banking business (linked to net interest } \\
\text { margin), including sales and trading, insurance sales, commissions, fees, and } \\
\text { advisory income divided by BHC total assets. Collected via Bloomberg }\end{array}$ \\
\hline 10. & ROA & Dependent & $\mathrm{ROA}$ is the return on total assets at year-end collected via Bloomberg. \\
\hline 11. & ROE & Dependent & $\mathrm{ROE}$ is the return on equity at year-end collected via Bloomberg. \\
\hline 12. & Risk appetite $\%$ & Explanatory & $\begin{array}{l}\text { Existence of risk appetite arrangements at the BHC board levels was hand- } \\
\text { collected from BHC risk committee charters collected }\end{array}$ \\
\hline 13. & Risk Committee \# & Explanatory & The risk committee number of members, as reported in BoardEx. \\
\hline 14. & $\begin{array}{l}\text { Risk Committee } \\
\text { financial } \\
\text { expertise } \%\end{array}$ & Explanatory & $\begin{array}{l}\text { Risk Committee member expertise is defined in Minton, Taillard and Williamson } \\
\text { (2014) and Güner et al. (2008) as independent director meeting the one of the } \\
\text { following criteria: has been an executive of a bank, an executive of a non-bank } \\
\text { financial institution, holds a financial position within a non-financial corporation, } \\
\text { holds an academic position related to the field, or works in fund or investment } \\
\text { management as a professional investor. This classification was determined using } \\
\text { BoardEx data and reviewing the biographical details for each director. }\end{array}$ \\
\hline 15. & Tail Risk & Dependent & $\begin{array}{l}\text { Tail Risk is defined as the negative of the average return on the firm's stock over } \\
\text { the five per cent worst days in a given year, following Ellul and Yerramilli (2013). } \\
\text { These authors explain that poorly designed incentives can encourage traders to } \\
\text { take on excessive risks that reward shareholders in the short term to only damage } \\
\text { the firm over time. Data collected from Bloomberg. }\end{array}$ \\
\hline 16. & Total loans $\%$ & Explanatory & Total loans are the total loans dividend by total assets as collected via Bloomberg. \\
\hline 17. & Z-score & Dependent & $\begin{array}{l}\text { We follow Laeven \& Levine (2009) and define the z-score the mean value of the } \\
\text { annual ROA plus Capital Asset Ratio or "CAR", divided by the standard deviation } \\
\text { of annual ROA for over each of the proceeding four years. For CAR, we collect } \\
\text { from Bloomberg the Total Risk-Based Capital Ratio (also known as the Capital } \\
\text { Adequacy Ratio). Where not available, we use Tier } 1 \text { \& } 2 \text { Capital to risk weighted } \\
\text { assets available from the US Federal Reserve. We use the log value in our } \\
\text { estimations. }\end{array}$ \\
\hline
\end{tabular}




\begin{tabular}{|c|c|c|c|c|c|c|}
\hline Variable & $\mathbf{N}$ & Mean & SD & Median & Min & Max \\
\hline Risk appetite $\%$ & 564 & 0.268 & 0.443 & 0 & 0 & 1 \\
\hline $\mathrm{CRO}$ age & 396 & 54.909 & 6.781 & 55 & 34 & 70 \\
\hline $\mathrm{RC}$ number & 375 & 5.04 & 1.745 & 5 & 0 & 12 \\
\hline BHC assets & 564 & 74.967 & 267877 & 72.019 & 1175 & 2.096 \\
\hline BHC assets $(\log )$ & 564 & 9.461 & 1.483 & 8.951 & 7.069 & 14.556 \\
\hline Number BOD meeting number & 470 & 10.189 & 3.992 & 10 & 2 & 26 \\
\hline BOD non-insider $\%$ & 557 & 0.868 & 0.074 & 0.889 & 0.167 & 1 \\
\hline Total loans \% & 560 & 64.222 & 15.738 & 67.885 & 5.529 & 96.167 \\
\hline Deposits $\%$ & 560 & 74.553 & 11.454 & 77.729 & 22.004 & 90.591 \\
\hline Institutional ownership $\%$ & 545 & 75.146 & 19.392 & 78.422 & 0.682 & 100 \\
\hline International activities \% & 564 & 0.03 & 0.095 & 0 & 0 & 0.58 \\
\hline ROA & 560 & 1.023 & 0.568 & 0.967 & -1.877 & 4.337 \\
\hline $\mathrm{ROE}$ & 560 & 9.096 & 5.096 & 8.87 & -17.717 & 49.251 \\
\hline Other operating income $\%$ & 561 & 0.0044 & 0.0159 & .00156 & -0.0120 & 0.1625 \\
\hline $\mathrm{HPR}$ & 535 & 20.683 & 26.998 & 15.317 & -24.218 & 284.158 \\
\hline Loan loss provisions & 536 & 0.201 & 0.309 & 0.137 & -1.248 & 2.062 \\
\hline Tail Risk & 541 & -27.568 & 25.383 & -20.157 & -221.74 & -3.306 \\
\hline Z-score & 530 & 10.61 & 13.55 & 6.67 & 151.48 & 0.163 \\
\hline
\end{tabular}




\section{Table 2: Correlations}

\begin{tabular}{|c|c|c|c|c|c|c|c|c|c|c|c|c|c|c|c|c|c|c|}
\hline & 1 & 2 & 3 & 4 & 5 & 6 & 7 & 8 & 9 & 10 & 11 & 12 & 13 & 14 & 15 & 16 & 17 & 18 \\
\hline 1.Risk Appetite & 1 & & & & & & & & & & & & & & & & & \\
\hline 2.CRO Age & -0.0602 & 1 & & & & & & & & & & & & & & & & \\
\hline 3.RC size & 0.0691 & -0.0254 & 1 & & & & & & & & & & & & & & & \\
\hline 4.BHC Size & $0.2813 *$ & -0.1111 & 0.0541 & 1 & & & & & & & & & & & & & & \\
\hline 5.\# BOD Meeting & 0.081 & $-0.1871 *$ & 0.0748 & $0.2263^{*}$ & 1 & & & & & & & & & & & & & \\
\hline 6.BOD non-insider & 0.0641 & 0.0114 & 0.0365 & $0.1712^{*}$ & 0.1096 & 1 & & & & & & & & & & & & \\
\hline 7.Total loans & $-0.1342 *$ & 0.1272 & -0.0873 & $-0.3240^{*}$ & -0.0105 & -0.0188 & 1 & & & & & & & & & & & \\
\hline 8.Deposits & $-0.2425 *$ & $0.1723^{*}$ & -0.0481 & $-0.3231 *$ & $-0.1819 *$ & -0.0105 & $0.3223 *$ & 1 & & & & & & & & & & \\
\hline 9.INST OWN & $0.2572^{*}$ & 0.088 & 0.008 & 0.0601 & 0.0425 & 0.032 & $-0.1251 *$ & $-0.1612^{*}$ & 1 & & & & & & & & & \\
\hline 10.International Act. & $0.2718^{*}$ & -0.1231 & 0.0901 & $0.5893^{*}$ & $0.2498^{*}$ & $0.1572^{*}$ & $-0.6068^{*}$ & $-0.5820^{*}$ & $0.1795^{*}$ & 1 & & & & & & & & \\
\hline 11.ROA & 0.1055 & 0.0287 & -0.0706 & -0.0319 & -0.0683 & -0.0446 & 0.0427 & -0.097 & 0.0883 & 0.042 & 1 & & & & & & & \\
\hline 12.ROE & 0.0426 & 0.0919 & -0.0517 & -0.0089 & -0.0396 & -0.0163 & 0.0252 & 0.0591 & 0.0317 & 0.0452 & $0.8796 *$ & 1 & & & & & & \\
\hline 13.Efficiency Ratio & -0.047 & -0.0739 & 0.0442 & 0.0299 & 0.0546 & 0.0569 & $-0.1760^{*}$ & $-0.1861 *$ & 0.1013 & $0.1405 *$ & $-0.4508^{*}$ & $-0.4891 *$ & 1 & & & & & \\
\hline 14.HPR & $-0.1487^{*}$ & 0.0097 & -0.0777 & 0.0205 & 0.0832 & 0.0355 & 0.0355 & 0.032 & -0.0453 & 0.008 & 0.056 & $0.1224 *$ & -0.0305 & 1 & & & & \\
\hline 15.LLP & 0.0613 & $-0.2001 *$ & -0.002 & 0.0518 & 0.1169 & 0.0787 & 0.061 & $-0.2016^{*}$ & -0.037 & $0.142^{*}$ & 0.0972 & 0.0553 & 0.0277 & $0.1819^{*}$ & 1 & & & \\
\hline 16.Margin & 0.0576 & 0.0921 & -0.0352 & -0.0359 & -0.08 & -0.0762 & $0.1472^{*}$ & $0.1645^{*}$ & -0.0448 & $-0.116^{*}$ & $0.4766^{*}$ & $0.4973 *$ & $-0.9353 *$ & -0.0157 & $-0.3731 *$ & 1 & & \\
\hline 17.Tail Risk & $-0.2686^{*}$ & 0.009 & $-0.1579 *$ & $-0.1210^{*}$ & 0.06 & $0.1776^{*}$ & $0.2901 *$ & $0.1372^{*}$ & $-0.2291 *$ & $-0.290^{*}$ & -0.105 & $-0.1420^{*}$ & 0.0603 & $0.1694 *$ & -0.0242 & -0.0734 & 1 & \\
\hline 18.Z score & 0.0216 & 0.0442 & 0.0496 & -0.0006 & -0.125 & -0.0523 & -0.0247 & $0.1233^{*}$ & $-0.1786^{*}$ & -0.103 & $0.1447 *$ & $0.2415^{*}$ & $-0.3664 *$ & $-0.2270 *$ & $-0.1270^{*}$ & $0.3729 *$ & -0.2729 & 1 \\
\hline
\end{tabular}


Table 3: BHC Performance \& Risk Determinants

Notes: $t$ statistics in parentheses. The dependent variable identified at the top of each column. Heteroskedasticity is corrected using robust standard errors. Estimations include year-dummies but not reported. Significance levels: $* \mathrm{p}<0.10, * * \mathrm{p}<0.05, * * * \mathrm{p}<0.01$

\begin{tabular}{|c|c|c|c|c|c|c|c|}
\hline & ROA & ROE & Other Op. Income & HPR & LLP & Z-score & Tail Risk \\
\hline \multirow[t]{2}{*}{$\begin{array}{l}\text { Risk } \\
\text { Appetite }\end{array}$} & $0.235^{* * *}$ & $1.659^{* *}$ & $0.00892 * * *$ & -1.927 & 0.0123 & 0.0433 & $-8.280 * * *$ \\
\hline & $(2.98)$ & $(2.50)$ & $(4.09)$ & $(-0.74)$ & $(0.39)$ & $(0.48)$ & $(-2.85)$ \\
\hline \multirow{2}{*}{ CRO Age } & -0.00617 & -0.0381 & 0.000226 & 0.229 & $-0.00947 * *$ & $-0.00942 *$ & 0.0644 \\
\hline & $(-0.95)$ & $(-0.74)$ & $(1.37)$ & $(1.40)$ & $(-2.52)$ & $(-1.81)$ & $(0.32)$ \\
\hline \multirow{2}{*}{$\mathrm{RC}$ size } & $-00242 *$ & $-0,183$ & $-0.00134^{* *}$ & -0.513 & 00144 & -000315 & $-3145 * *$ \\
\hline & $(-1.70)$ & $(-1.50)$ & $(-2.02)$ & $(-1.00)$ & $(1.26)$ & $(-0.15)$ & $(-2.56)$ \\
\hline \multirow{2}{*}{ BHC Size } & 0.0350 & $0.553 * *$ & $-0.00429 * * *$ & 1.443 & $0.0254 *$ & $0.0873 * * *$ & -1.485 \\
\hline & $(1.04)$ & $(2.24)$ & $(-3.97)$ & $(1.49)$ & $(1.76)$ & $(3.08)$ & $(-1.26)$ \\
\hline \multirow{3}{*}{$\begin{array}{l}\# \text { BOD } \\
\text { Meeting } \\
\end{array}$} & & & & & & & \\
\hline & $-0.034 * * *$ & $-0.286^{* * *}$ & $-0.00103^{* * *}$ & -0.156 & $\begin{array}{l}-0.00526 \\
\end{array}$ & -0.00407 & 0.418 \\
\hline & $(-3.53)$ & $(-3.64)$ & $(-3.60)$ & $(-0.58)$ & $(-1.24)$ & $(-0.43)$ & $(1.24)$ \\
\hline \multirow{2}{*}{$\begin{array}{l}\text { BOD non- } \\
\text { insider }\end{array}$} & 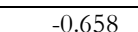 & $-7.157^{*}$ & $0.0587 * * *$ & 9223 & $0719 * * *$ & -1 794*** & $1072 * * *$ \\
\hline & $(-1.16)$ & $(-1.81)$ & $(3.64)$ & $(0.65)$ & $(2.90)$ & $(-3.58)$ & $(3.61)$ \\
\hline \multirow{2}{*}{ Total loans } & $0.0116^{* * *}$ & $0.0749 * *$ & $0.000173^{* *}$ & 0.113 & $0.00698^{* * *}$ & -0.00329 & $0.379 * * *$ \\
\hline & $(3.35)$ & $(2.53)$ & $(2.04)$ & $(1.25)$ & $(3.20)$ & $(-1.23)$ & $(3.04)$ \\
\hline \multirow{2}{*}{ Deposits } & -0.00767 & 0.00349 & $-0.00105^{* * *}$ & 0.0620 & $-0.00834 * *$ & $0.00772^{* *}$ & 0.0237 \\
\hline & $(-1.10)$ & $(0.07)$ & $(-4.32)$ & $(0.63)$ & $(-2.54)$ & $(2.15)$ & $(0.16)$ \\
\hline \multirow{3}{*}{$\begin{array}{l}\text { Institutional } \\
\text { Ownership }\end{array}$} & 000148 & 0.0107 & $0.000233 * * *$ & 00223 & $000363 * * *$ & $-0.00393 *$ & $-0.221 * *$ \\
\hline & & & & & & & \\
\hline & $(0.70)$ & $(0.62)$ & $(3.66)$ & $(0.28)$ & $(2.74)$ & $(-1.65)$ & $(-2.22)$ \\
\hline & & & & & & & \\
\hline \multirow[t]{2}{*}{$\begin{array}{l}\text { International } \\
\text { Activities }\end{array}$} & 0.860 & $9.050^{*}$ & $0.0315^{*}$ & 19.73 & 0.170 & -0.668 & -20.46 \\
\hline & $(1.49)$ & $(1.92)$ & $(1.85)$ & $(1.41)$ & $(0.57)$ & $(-1.52)$ & $(-1.08)$ \\
\hline \multirow{2}{*}{ Constant } & $1.622^{* *}$ & $8.335^{*}$ & $0.0440^{* *}$ & $-44.66^{* *}$ & -0.175 & $2.298^{* * * *}$ & $-107.4^{* * *}$ \\
\hline & $(2.28)$ & $(1.69)$ & $(2.30)$ & $(-2.11)$ & $(-0.48)$ & $(4.03)$ & $(-3.70)$ \\
\hline Observations & 250 & 250 & 250 & 247 & 235 & 240 & 248 \\
\hline Adjusted $R^{2}$ & 0.1925 & 0.1488 & 0.4997 & 0.5442 & 0.2928 & 0.3011 & 0.3946 \\
\hline
\end{tabular}


Table 4: BHC Performance \& Risk Determinants (one-year lag)

Notes: $t$ statistics in parentheses. The dependent variable identified at the top of each column. Heteroskedasticity is corrected using robust standard errors. Estimations include year-dummies but not reported. Significance levels: $* \mathrm{p}<0.10, * * \mathrm{p}<0.05, * * * \mathrm{p}<0.01$

\begin{tabular}{|c|c|c|c|c|c|c|c|}
\hline & ROA & ROE & Other Op. Income & HPR & LLP & Z-score & Tail Risk \\
\hline \multirow[t]{2}{*}{$\begin{array}{l}\text { Risk } \\
\text { Appetite }\end{array}$} & $0.300^{* * *}$ & $1.843^{* * * *}$ & $0.0112^{* * *}$ & -0.351 & $0.0933^{* * *}$ & $0.206^{* *}$ & -6.721 \\
\hline & $(3.82)$ & $(2.78)$ & $(4.03)$ & $(-0.15)$ & $(2.66)$ & $(2.48)$ & $(-1.65)$ \\
\hline \multirow{2}{*}{ CRO Age } & -0.00363 & -0.0198 & 0.000217 & 0.0958 & $-0.00987 * *$ & -0.00856 & -0.0315 \\
\hline & $(-0.58)$ & $(-0.39)$ & $(1.14)$ & $(0.66)$ & $(-2.45)$ & $(-1.57)$ & $(-0.13)$ \\
\hline \multirow{2}{*}{$\mathrm{RC}$ size } & $-0.0358 * *$ & $-0270 * *$ & $-0,00143 *$ & -0210 & 00165 & -0.0261 & $3460 * *$ \\
\hline & $(-2.09)$ & $(-2.02)$ & $(-1.85)$ & $(-0.49)$ & $(1.21)$ & $(-1.23)$ & $(-2.28)$ \\
\hline \multirow{2}{*}{ BHC Size } & 0.00956 & $0.443 *$ & $-0.00418^{* * *}$ & 0.907 & 0.00857 & $0.0578^{* *}$ & -1.786 \\
\hline & $(0.35)$ & $(1.89)$ & $(-3.62)$ & $(1.20)$ & $(0.58)$ & $(2.09)$ & $(-1.19)$ \\
\hline \multirow{3}{*}{$\begin{array}{l}\# \text { BOD } \\
\text { Meeting } \\
\end{array}$} & & & & & & & \\
\hline & $-0.0427 * * *$ & $-0.342^{* * *}$ & $-0.000862 * * *$ & $\begin{array}{c}-0.168 \\
\end{array}$ & $-0.00756^{*}$ & -0.0102 & 0.215 \\
\hline & $(-5.23)$ & $(-4.88)$ & $(-3.08)$ & $\begin{array}{l}(-0.62) \\
\end{array}$ & $(-1.82)$ & $(-1.13)$ & $(0.53)$ \\
\hline \multirow{2}{*}{$\begin{array}{l}\text { BOD non- } \\
\text { insider }\end{array}$} & -0.508 & $-6,072$ & $0.0590 * * *$ & -4.731 & $0575^{* *}$ & $-1,50 * * *$ & $1122 * * *$ \\
\hline & $(-0.95)$ & $(-1.58)$ & $(3.31)$ & $(-0.38)$ & $(2.26)$ & $(-2.98)$ & $(3.05)$ \\
\hline \multirow{2}{*}{ Total loans } & $0.0114 * * *$ & $0.0750 * *$ & 0.000114 & -0.0336 & $0.00588 * *$ & -0.00450 & $0.396 * *$ \\
\hline & (3.23) & $(2.44)$ & $(1.24)$ & $(-0.35)$ & $(2.22)$ & $(-1.55)$ & $(2.49)$ \\
\hline \multirow{2}{*}{ Deposits } & $-0.0160 * * *$ & $\begin{array}{l}-0.0479 \\
\end{array}$ & $-0.00106^{* * * *}$ & 0.0730 & $-0.0103 * * *$ & $0.00613 *$ & 0.111 \\
\hline & $(-2.74)$ & $(-0.98)$ & $(-3.92)$ & $(0.66)$ & $(-3.06)$ & $(1.70)$ & $(0.59)$ \\
\hline \multirow{3}{*}{$\begin{array}{l}\text { Institutional } \\
\text { Ownership }\end{array}$} & 0.00256 & 0.0137 & $0.000214 * * *$ & 00985 & $000380 * * *$ & $-0.00526 * *$ & $-0235 *$ \\
\hline & & & & & & & \\
\hline & $(1.35)$ & $(0.84)$ & $(3.10)$ & $(1.41)$ & $(2.78)$ & $(-2.26)$ & $(-1.90)$ \\
\hline \multirow{3}{*}{$\begin{array}{l}\text { International } \\
\text { Activities }\end{array}$} & 1.000 & $10.36 * *$ & 0.0263 & 4099 & 0181 & 0705 & 2088 \\
\hline & & & & & & & \\
\hline & $(1.63)$ & $(1.99)$ & $(1.37)$ & $(-0.29)$ & $(0.50)$ & $(-1.39)$ & $(-0.90)$ \\
\hline \multirow{2}{*}{ Constant } & $2.274 * * *$ & $12.11 * * *$ & $0.0485^{* *}$ & -18.30 & 0.132 & $2.349 * * *$ & $-101.0^{* * *}$ \\
\hline & $(3.53)$ & $(3.04)$ & $(2.44)$ & $(-1.01)$ & $(0.36)$ & $(4.47)$ & $(-2.86)$ \\
\hline Observations & 195 & 195 & 195 & 194 & 182 & 190 & 193 \\
\hline Adjusted $R^{2}$ & 0.3272 & 0.2275 & 0.5050 & 0.6790 & 0.3262 & 0.2282 & 0.3935 \\
\hline
\end{tabular}


Table 5: BHC Performance \& Risk Determinants (two-year lag)

Notes: $t$ statistics in parentheses. The dependent variable identified at the top of each column. Heteroskedasticity is corrected using robust standard errors. Estimations include year-dummies but not reported. Significance levels: $* \mathrm{p}<0.10, * * \mathrm{p}<0.05, * * * \mathrm{p}<0.01$

\begin{tabular}{|c|c|c|c|c|c|c|c|}
\hline & ROA & ROE & Other Op. Income & HPR & LLP & Z-score & Tail Risk \\
\hline \multirow[t]{2}{*}{$\begin{array}{l}\text { Risk } \\
\text { Appetite }\end{array}$} & $0.309^{* * *}$ & $2.381^{* * * *}$ & $0.0131^{* * *}$ & -0.704 & $0.102 * *$ & $0.182^{*}$ & -1.923 \\
\hline & (3.31) & $(3.08)$ & (3.14) & $(-0.27)$ & $(2.00)$ & $(1.68)$ & $(-0.32)$ \\
\hline \multirow{2}{*}{ CRO Age } & -0.00123 & -0.00622 & 0.000207 & -0.0344 & $-0.0103 *$ & -0.00324 & -0.158 \\
\hline & $(-0.15)$ & $(-0.10)$ & $(0.82)$ & $(-0.22)$ & $(-1.81)$ & $(-0.46)$ & $(-0.45)$ \\
\hline \multirow{2}{*}{$\mathrm{RC}$ size } & -0.0293 & -0.267 & $-0,00148$ & 0.162 & 000010 & -0.0135 & $-3707 *$ \\
\hline & $(-1.37)$ & $(-1.54)$ & $(-1.63)$ & $(0.32)$ & $(0.49)$ & $(-0.48)$ & $(-1.89)$ \\
\hline \multirow{2}{*}{ BHC Size } & -0.00213 & 0.299 & $-0.00434 * * *$ & 1.132 & 0.00664 & $0.0724 *$ & $-3.438 *$ \\
\hline & $(-0.06)$ & $(1.01)$ & $(-2.81)$ & $(1.38)$ & $(0.36)$ & $(1.91)$ & $(-1.74)$ \\
\hline \multirow{3}{*}{$\begin{array}{l}\# \text { BOD } \\
\text { Meeting } \\
\end{array}$} & & & & & & & \\
\hline & $-0.0467 * * *$ & $-0.352^{* * *}$ & $-0.000850^{* *}$ & 0.0454 & -0.00744 & -0.00796 & 0.669 \\
\hline & $(-4.54)$ & $(-4.05)$ & $(-2.30)$ & $(0.15)$ & $(-1.36)$ & $(-0.69)$ & $(1.24)$ \\
\hline \multirow{2}{*}{$\begin{array}{l}\text { BOD non- } \\
\text { insider }\end{array}$} & -0.533 & $\begin{array}{c}-5.434 \\
-1\end{array}$ & $0.0552 * *$ & -21.52 & 0483 & $-1316 * *$ & 1235 ** \\
\hline & $(-0.80)$ & $(-1.24)$ & $(2.45)$ & $(-1.53)$ & $(1.50)$ & $(-2.37)$ & $(2.36)$ \\
\hline \multirow{2}{*}{ Total loans } & $0.0109 * *$ & $0.0735^{*}$ & 0.0000250 & 0.0627 & 0.00396 & -0.00215 & 0.323 \\
\hline & $(2.50)$ & $(1.95)$ & $(0.21)$ & $(0.59)$ & $(1.07)$ & $(-0.55)$ & $(1.48)$ \\
\hline \multirow{2}{*}{ Deposits } & $-0.0180 * *$ & -0.0486 & $-0.00101 * * *$ & 0.142 & $-0.0117 * * *$ & 0.00681 & 0.154 \\
\hline & $(-2.48)$ & $(-0.82)$ & $(-2.94)$ & $(1.15)$ & $(-2.78)$ & $(1.59)$ & $(0.61)$ \\
\hline \multirow{3}{*}{$\begin{array}{l}\text { Institutional } \\
\text { Ownership }\end{array}$} & 000168 & 0.00150 & $0000170 * *$ & -0.0368 & $0,00528 * *$ & $-0.00592 *$ & -0.249 \\
\hline & & & & & & & \\
\hline & $(0.72)$ & $(0.08)$ & $(2.03)$ & $(-0.48)$ & $(2.57)$ & $(-1.88)$ & $(-1.47)$ \\
\hline \multirow{3}{*}{$\begin{array}{l}\text { International } \\
\text { Activities }\end{array}$} & & & & & & & \\
\hline & 1.158 & $11.95^{*}$ & 0.0231 & 7.026 & -0.0476 & -0.824 & -29.02 \\
\hline & $(1.48)$ & $(1.76)$ & $(0.93)$ & $(0.44)$ & $(-0.10)$ & $(-1.22)$ & $(-0.87)$ \\
\hline \multirow{2}{*}{ Constant } & $2.535^{* * * *}$ & $13.30^{* *}$ & $0.0597 * *$ & -2.613 & 0.417 & $1.930^{* * * *}$ & $-94.67 *$ \\
\hline & $(2.87)$ & $(2.43)$ & $(2.24)$ & $(-0.15)$ & $(0.84)$ & (3.34) & $(-1.98)$ \\
\hline Observations & 127 & 127 & 127 & 126 & 118 & 123 & 125 \\
\hline Adjusted $R^{2}$ & 0.3226 & 0.2246 & 0.4779 & 0.6986 & 0.3098 & 0.1863 & 0.3873 \\
\hline
\end{tabular}


Table 6: BHC Performance \& Risk Determinants (mandatory adopters)

Notes: $t$ statistics in parentheses. The dependent variable identified at the top of each column. Heteroskedasticity is corrected using robust standard errors. Estimations include year-dummies but not reported. Significance levels: $* \mathrm{p}<0.10,{ }^{* *} \mathrm{p}<0.05,{ }^{* * *} \mathrm{p}<0.01$

\begin{tabular}{|c|c|c|c|c|c|c|c|}
\hline & ROA & ROE & Other Op. Income & HPR & LLP & Z-score & Tail Risk \\
\hline \multirow[t]{2}{*}{$\begin{array}{l}\text { Risk } \\
\text { Appetite }\end{array}$} & $0.275^{*}$ & $2.589^{* *}$ & $0.0108^{* *}$ & -5.990 & -0.00707 & $0.271^{* *}$ & -8.655 \\
\hline & $(1.83)$ & $(2.17)$ & $(2.03)$ & $(-1.38)$ & $(-0.08)$ & $(2.53)$ & $(-1.64)$ \\
\hline \multirow{2}{*}{ CRO Age } & -0.0135 & -0.130 & 0.000951 & 0.379 & $-0.0182^{* *}$ & $-0.0205^{* *}$ & $1.021 * *$ \\
\hline & $(-0.92)$ & $(-1.15)$ & $(1.50)$ & $(1.06)$ & $(-2.29)$ & $(-2.22)$ & $(2.18)$ \\
\hline \multirow{2}{*}{ RC size } & -0.0234 & -0235 & $-0.00294 * *$ & -0382 & -000476 & 000193 & $-5676 * * *$ \\
\hline & $(-1.02)$ & $(-1.32)$ & $(-2.61)$ & $(-0.52)$ & $(-0.24)$ & $(0.13)$ & $(-4.71)$ \\
\hline \multirow{2}{*}{ BHC Size } & $-0100 * *$ & $-0.875 * *$ & $-000304 *$ & 0.146 & -0.0727 & 00280 & 2794 \\
\hline & $(-2.37)$ & $(-2.32)$ & $(-1.91)$ & $(0.08)$ & $(-1.55)$ & $(0.73)$ & $(1.21)$ \\
\hline \multirow{3}{*}{$\begin{array}{l}\# \text { BOD } \\
\text { Meeting } \\
\end{array}$} & & & & & & & \\
\hline & $-0.0665^{* * *}$ & -0.671 *** & $\begin{array}{l}-0.000992 \\
\end{array}$ & 0.229 & -0.00932 & $-0.0395 * * *$ & $2.484^{* * *}$ \\
\hline & $(-3.72)$ & $(-4.55)$ & $(-1.29)$ & $(0.48)$ & $(-0.86)$ & $(-3.11)$ & $(3.07)$ \\
\hline \multirow{3}{*}{$\begin{array}{l}\text { BOD non- } \\
\text { insider }\end{array}$} & & & & & & & \\
\hline & $2.258^{*}$ & 11.69 & $0.126^{* *}$ & 39.10 & $1.641 *$ & -1.129 & $453.7^{* * *}$ \\
\hline & $(1.84)$ & $(1.07)$ & $(2.19)$ & $\begin{array}{l}(0.96) \\
\end{array}$ & $(1.86)$ & $(-0.98)$ & $(4.99)$ \\
\hline \multirow{2}{*}{ Total loans } & $0.0252 * * *$ & $0.157 * * *$ & $0.000251 *$ & 0.128 & $0.0147^{* * *}$ & -0.000451 & -0.0186 \\
\hline & $(6.57)$ & $(4.90)$ & $(1.74)$ & $(1.02)$ & $(5.75)$ & $(-0.16)$ & $(-0.14)$ \\
\hline \multirow[t]{2}{*}{ Deposits } & $-0.0215^{* * *}$ & $-0.139 * *$ & $-0.00117^{* * *}$ & -0.104 & $-0.0180^{* * * *}$ & 0.00294 & $0.288^{*}$ \\
\hline & $(-2.94)$ & $(-2.60)$ & $(-3.21)$ & $(-0.77)$ & $(-4.45)$ & $(0.94)$ & $(1.74)$ \\
\hline \multirow{2}{*}{$\begin{array}{l}\text { Institutional } \\
\text { Ownership }\end{array}$} & $0.0157^{* * *}$ & $0.0828^{*}$ & $0.000637^{* *}$ & -0.0155 & $0.0128^{* *}$ & 0.00101 & 0.260 \\
\hline & $(2.67)$ & $(1.72)$ & $(2.20)$ & $(-0.07)$ & $(2.09)$ & $(0.21)$ & $(0.71)$ \\
\hline & & & & & & & \\
\hline \multirow[t]{2}{*}{$\begin{array}{l}\text { International } \\
\text { Activities }\end{array}$} & $2.010^{* * *}$ & $17.99^{* * *}$ & 0.00653 & 12.71 & $0.889 *$ & 0.109 & $-78.92^{* * *}$ \\
\hline & $(3.39)$ & $(3.51)$ & $(0.31)$ & $(0.69)$ & $(1.90)$ & $(0.26)$ & $(-3.31)$ \\
\hline \multirow{2}{*}{ Constant } & 0.208 & 15.60 & $\begin{array}{l}-0.0913 \\
\end{array}$ & $\begin{array}{c}-56.74 \\
\end{array}$ & 0.0825 & 2.121 & $-549.5^{* * *}$ \\
\hline & $(0.12)$ & $(1.05)$ & $(-1.13)$ & $(-1.13)$ & $(0.05)$ & $(1.47)$ & $(-5.24)$ \\
\hline Observations & 87 & 87 & 87 & 86 & 78 & 84 & 87 \\
\hline Adjusted $R^{2}$ & 0.6278 & 0.5645 & 0.437 & 0.604 & 0.624 & 0.434 & 0.590 \\
\hline
\end{tabular}


Table 7: BHC Performance \& Risk Determinants (risk committee financial expertise added as explanatory variable)

Notes: $t$ statistics in parentheses. The dependent variable identified at the top of each column. Heteroskedasticity is corrected using robust standard errors. Estimations include year-dummies but not reported. Significance levels: ${ }^{*} \mathrm{p}<0.10,{ }^{* *} \mathrm{p}<0.05,{ }^{* * *} \mathrm{p}<0.01$

\begin{tabular}{|c|c|c|c|c|c|c|c|}
\hline & ROA & ROE & Other Op. Income & HPR & LLP & Z-score & Tail Risk \\
\hline RC Financial & -0.344 & -2.477 & -0.00923 & $11.59^{* *}$ & 0.0575 & $-0.459 * * *$ & 2.100 \\
\hline Expertise & $(-1.55)$ & $(-1.27)$ & $(-1.39)$ & $(2.25)$ & $(0.58)$ & $(-2.83)$ & $(0.35)$ \\
\hline \multirow{3}{*}{$\begin{array}{l}\text { Risk } \\
\text { Appetite }\end{array}$} & & & & & & & \\
\hline & $0.234^{* *}$ & $1.813^{* *}$ & $0.00886^{* * *}$ & -0.988 & -0.00399 & 0.0989 & $-5.734 *$ \\
\hline & $(2.55)$ & $(2.34)$ & $(3.61)$ & $(-0.35)$ & $(-0.11)$ & $(0.91)$ & $(-1.83)$ \\
\hline \multirow{2}{*}{ CRO Age } & -0.00592 & -0.0245 & $0.000249 *$ & 0.289 & $-0.00890 * *$ & $-0.0105^{*}$ & 0.113 \\
\hline & $(-0.86)$ & $(-0.45)$ & $(1.69)$ & $(1.64)$ & $(-2.29)$ & $(-1.80)$ & $(0.56)$ \\
\hline \multirow{2}{*}{ RC size } & $-0,0316 *$ & -0.180 & $-000128 *$ & -0247 & 00110 & -0.0184 & $-2350 *$ \\
\hline & $(-1.82)$ & $(-1.15)$ & $(-1.69)$ & $(-0.38)$ & $(0.89)$ & $(-0.72)$ & $(-1.78)$ \\
\hline \multirow{2}{*}{ BHC Size } & 0.0407 & $0.571^{*}$ & $-0,00433 * * *$ & 1646 & $00278 *$ & $00788^{* *}$ & -1612 \\
\hline & $(1.02)$ & $(1.96)$ & $(-3.54)$ & $(1.47)$ & $(1.71)$ & $(2.38)$ & $(-1.36)$ \\
\hline \multirow{3}{*}{$\begin{array}{l}\text { \# BOD } \\
\text { Meeting }\end{array}$} & & & & & & & \\
\hline & $-0.0317 * * *$ & $-0.284 * * *$ & $-0.000992^{* * *}$ & -0.191 & -0.00620 & 0.000246 & 0.373 \\
\hline & $(-3.00)$ & $(-3.43)$ & $(-3.20)$ & $(-0.70)$ & $(-1.36)$ & $(0.02)$ & $(1.10)$ \\
\hline \multirow{2}{*}{$\begin{array}{l}\text { BOD non- } \\
\text { insider }\end{array}$} & -0.865 & $-7.415^{*}$ & $0.0501 * * *$ & $27.72^{*}$ & $0.802^{* * *}$ & $-2.055^{* * *}$ & $94,19 * * *$ \\
\hline & $(-1.33)$ & $(-1.68)$ & $(3.08)$ & $(1.80)$ & $(2.82)$ & $(-3.66)$ & (3.13) \\
\hline \multirow[t]{2}{*}{ Total loans } & $0.0121^{* * *}$ & $0.0776^{* *}$ & $0.000215^{* *}$ & 0.0555 & $0.00825^{* * *}$ & -0.00344 & $0.356^{* * * *}$ \\
\hline & (3.05) & $(2.31)$ & $(2.44)$ & $(0.58)$ & $(3.37)$ & $(-1.13)$ & $(2.61)$ \\
\hline \multirow[t]{2}{*}{ Deposits } & -0.00440 & 0.0260 & $-0.00101 * * *$ & 0.0411 & $-0.00681 *$ & $0.00819^{* *}$ & -0.0390 \\
\hline & $(-0.59)$ & $(0.47)$ & $(-3.97)$ & $(0.39)$ & $(-1.91)$ & $(2.07)$ & $(-0.23)$ \\
\hline \multirow{3}{*}{$\begin{array}{l}\text { Institutional } \\
\text { Ownership }\end{array}$} & 0.00148 & 0.0103 & $0.000226 * * *$ & 0,0100 & $0.00361 * *$ & $-0,00446$ & $-0.260 * *$ \\
\hline & & & & & & & \\
\hline & $(0.65)$ & $(0.55)$ & $(3.29)$ & $(0.11)$ & $(2.51)$ & $(-1.57)$ & $(-2.47)$ \\
\hline & & & & & & & \\
\hline \multirow[t]{2}{*}{$\begin{array}{l}\text { International } \\
\text { Activities }\end{array}$} & 1.091 & $10.73^{*}$ & $0.0416^{* *}$ & 15.11 & 0.323 & -0.250 & -22.11 \\
\hline & $(1.57)$ & $(1.89)$ & $(2.44)$ & $(0.92)$ & $(0.93)$ & $(-0.50)$ & $(-1.09)$ \\
\hline \multirow{2}{*}{ Constant } & $1666 *$ & 7,664 & $00522 * * *$ & $4267 *$ & 0.507 & $2016 * * *$ & $0511 * * *$ \\
\hline & $(1.95)$ & $(1.28)$ & $(2.71)$ & $\frac{-24.0}{(-1.77)}$ & $(-1.25)$ & $\frac{1.010}{(3.93)}$ & $\frac{-0.11}{(-2.91)}$ \\
\hline Observations & 203 & 203 & 203 & 200 & 191 & 194 & 202 \\
\hline Adjusted $R^{2}$ & 0.1799 & 0.1527 & 0.5298 & 0.498 & 0.243 & 0.2784 & 0.315 \\
\hline
\end{tabular}


Table 8: BHC Differences-in-Differences Analysis

Differences-in-Differences analysis. The dependent variable identified at the top of each column. Control variables used in the above estimations are used in all Differences-in-Differences models as co-variates. Significance levels: ${ }^{*} \mathrm{p}<0.10,{ }^{* *} \mathrm{p}<0.05,{ }^{* * *} \mathrm{p}<0.01$.

\begin{tabular}{|c|c|c|c|c|c|c|c|}
\hline & $\mathrm{ROA}$ & ROE & Other Op. Income & HPR & LLP & Z-score & Tail Risk \\
\hline $\begin{array}{l}>|t| \\
\text { Baseline }\end{array}$ & 0.305 & 0.410 & 0.145 & 0.819 & 0.452 & 0773 & 0.448 \\
\hline $\begin{array}{l}\mathrm{P}>|\mathrm{t}| \\
\text { Follow up }\end{array}$ & $0.000^{* * *}$ & $0.003^{* * *}$ & $0.000^{* * *}$ & $0.014^{* *}$ & 0.536 & 0.144 & $0.000^{* * *}$ \\
\hline $\begin{array}{l}\text { Differences- } \\
\text { in- } \\
\text { Differences } \\
\end{array}$ & $0.005 * * *$ & $0.025 * *$ & 0.664 & 0.309 & 0.317 & 0.338 & $-0.011^{* *}$ \\
\hline Observations & 250 & 250 & 250 & 247 & 235 & 240 & 248 \\
\hline $\begin{array}{l}\text { Control } \\
\text { (Baseline) }\end{array}$ & 37 & 37 & 37 & 35 & 35 & 35 & 37 \\
\hline $\begin{array}{l}\text { Control } \\
\text { (Follow up) }\end{array}$ & 106 & 106 & 106 & 105 & 97 & 101 & 104 \\
\hline $\begin{array}{l}\begin{array}{l}\text { Treated } \\
\text { (Baseline) }\end{array} \\
\end{array}$ & 18 & 18 & 18 & 18 & 18 & 15 & 18 \\
\hline $\begin{array}{l}\text { Treated } \\
\text { (Follow up) }\end{array}$ & 89 & 89 & 89 & 89 & 85 & 89 & 89 \\
\hline R-square & 0.22 & 0.1700 & 0.5000 & 0.0700 & 0.2900 & 0.2500 & 0.4000 \\
\hline
\end{tabular}




\section{Endnotes}

${ }^{1}$ See the Financial Crisis Inquiry Report (2011); Levine (2012); Prager (2013) and Saunders \& Cornett (2018) for more background on the global financial crisis.

2 In this study, we use the phrase risk appetite frameworks and risk appetite arrangements interchangeably, which defines the overarching policies, processes, controls and systems required to communicate and monitor risk appetite (FSB, 2013).

${ }^{3}$ The risk governance framework is defined as the means which the board and management establish the firm's strategy; articulate and monitor adherence to risk appetite and risk limits; and identify, measure and manage risks (FSB, 2013).

${ }^{4}$ The Senior Supervisors Group (SSG) is a group of bank supervisory agencies from leading centers in the US, UK, Switzerland, Germany and France.

${ }^{5}$ For a review of the regulatory response applicable to market risk and the trading book, see Alexander, Baptista \& Yan (2015).

${ }^{6}$ For an in-depth review of how risk appetite frameworks may practically work in financial institutions and drive performance gains, see Jackson (2014).

${ }^{7}$ A forum of senior supervisory authorities and other representatives which evaluate risk management practices, governance, and other issues concerning complex, globally-active financial institutions.

8 The risk committee is the board-level sub-committee delegated with the oversight and monitoring of bank-wide risk profiles, comprised largely and chaired by non-insider directors. 
${ }^{9}$ Large US BHCs were required to adopt risk appetite practices in September 2014 (Federal Register, 2014a).

10 An example of a BHC risk committee charter may be found for example or SunTrust Banks Inc., a US BHC, at

http://investors.suntrust.com/governance/corporate-governance-documents/default.aspx. We acknowledge one weakness of using this dummy variable is that it cannot be taken for granted that information publically disseminated by BHCs generally reflects actual risk governance practices followed; however, at a minimum, its unambiguous publication sends a strong signal of its practice across the firm. See the Deloitte series of Risk Committee Charters for US banks available at https://www2.deloitte.com/content/dam/insights/us/articles/4106 bank-board-risk-governance/4106 bank-board-risk-governance.pdf and a sample risk committee charter produced by Deloittes at https://www2.deloitte.com/za/en/pages/governance-risk-and-compliance/articles/sample-risk-committeecharter.html.

${ }^{11}$ The authors wish to thank Dr Ed Altman of NYU Stern for his input here to distinguish different methodologies for the z-score between large industrials, other corporate entities, and the bank-related approach we have adopted in our research. See Chiaramonte et al., 2016 for further background.

12 Seminal literature defines this variable as director holding previous executive responsibilities in a banking firm, executive responsibilities in a non-bank financial firm or executive financial responsibilities in a non-financial firm, or being an academic in finance or a related discipline, or a professional investor, following Minton, Taillard and Williamson, 2014, p.355 and other literature). 
13 We also test in un-reported results for specifically when the chairman of the BHC risk committee satisfies this same expertise definition as a dummy variable and rerun the baseline estimations, given that the leader of this board sub-committee may have notable influence over risk oversight, but again the results are the same as before and this predictor value does not explain our results observed earlier.

${ }^{14}$ In our sample, twenty BHCs were already treated (i.e. already adopted risk appetite) in the first year of the sample in 2012, so the impact of these early adopters was coded in order to ensure all BHCs were reported as untreated in 2012 (effectively removing treated BHCs from the pre-treatment period). In this way, the sample now includes only untreated BHCs for 2012. We appreciate such an approach may introduce sample bias, but it is the best solution facilitating the use of this technique with our data set. 